Article

\title{
Effects of Various Drying Methods on Some Physico-Chemical Properties and the Antioxidant Profile and ACE Inhibition Activity of Oyster Mushrooms (Pleurotus Ostreatus)
}

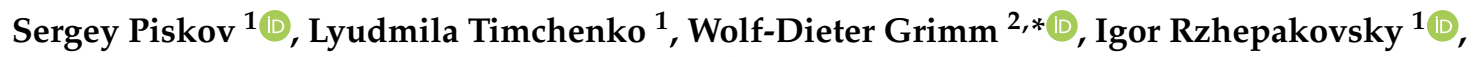 \\ Svetlana Avanesyan ${ }^{1} \mathbb{D}$, Marina Sizonenko ${ }^{1} \mathbb{D}$ and Vladimir Kurchenko ${ }^{3}$ \\ 1 Institute of Live Science, North Caucasus Federal University, 355017 Stavropol, Russia; \\ piskovsi77@mail.ru (S.P.); 1_timchenko@mail.ru (L.T.); 78igorr@mail.ru (I.R.); s.avanesan@yandex.ru (S.A.); \\ risha_veresk@mail.ru (M.S.) \\ 2 Periodontology, School of Dentistry, Faculty of Health, Witten/Herdecke University, A.-Herrhausen-Street 50, \\ 58448 Witten, Germany \\ 3 Faculty of Biology, Belarusian State University, 220030 Minsk, Belarus; kurchenko@tut.by \\ * Correspondence: prof_wolf.grimm@yahoo.de; Tel.: +49-233-9911-160
}

Received: 28 December 2019; Accepted: 1 February 2020; Published: 7 February 2020

check for updates

\begin{abstract}
In food biotechnology, Pleurotus ostreatus is of great interest as a source of natural antioxidants and angiotensin-converting enzyme (ACE) inhibitors. However, research in this area has not yet been completed. The effect of various drying methods on the structural properties and the rehydration capacity of mushrooms was investigated in this paper. The content of secondary metabolites, the peptide profile, and the antioxidative effect and ACE inhibitory activity of dry mushrooms were investigated in vitro, simulating the process of gastrointestinal digestion. X-ray microtomography has confirmed that structure of lyophilic and sun-dried mushrooms is dominated by open pores, and in mushrooms dried with hot air and microwave, closed pores. Experiments have shown that the conditions of freeze drying and sun drying of Pleurotus ostreatus provide a higher rehydration capacity of dried mushrooms. The maximum activity of radical absorption of the oyster mushroom after microwave drying was observed. The iron restoring capacity of the mushrooms is maximally maintained with microwave drying and hot-air drying. The properties of the antioxidant product with an emphasis on the high activity of inhibiting lipid oxidation of the mushroom maximized after drying in the sun. Mushrooms dried lyophilically and in the sun showed the highest ACE inhibitory activity.
\end{abstract}

Keywords: drying; oyster mushrooms; antioxidant activity; ACE inhibitory activity

\section{Introduction}

Recently, interest in natural antioxidants and their use in the production of a new generation of foods has increased. Epidemiological studies [1] have highlighted the close link between foods that are rich in antioxidants Reactive oxygen species (ROS) with systemic health diseases [2]. ROS, especially when human in vivo antioxidant defense and immunological repair systems are inadequate to prevent the damage. Oxidative stress has been associated with hypertension development [3]. If hypertension persists over a long period of time, this is one of the risks for strokes, heart disease, and eventually for the emergence of chronic kidney failure.

According to recent studies, oxidative stress is involved in the mechanisms of metabolic syndrome [4]. Metabolic syndrome, in turn, can be a leading risk factor for cardiovascular disease, 
type II diabetes mellitus, reproductive pathology and several common cancers [5]. A parallel study provided by our international research team on the combination of metabolic syndrome (MS) and chronic obstructive pulmonary disease (COPD) revealed pathological mechanisms linking MS and COPD [6].

The intake of exogenous antioxidants is critical to maintaining adequate levels of antioxidants to ensure balance with prevention of the aforementioned pathologies.

Special attention is paid in this context to the mushrooms. Due to the large number of biologically active substances they are of interest as valuable raw materials for functional products, especially those with antioxidant effects $[7,8]$. Oyster mushrooms are promising in this respect as their fruiting bodies are readily available and rich in natural antioxidants $[9,10]$.

However, it should be noted that the content and efficacy of biologically active compounds in mushrooms vary widely, not only depending on the species, growing conditions and maturity [11,12], but also on storage and processing methods $[13,14]$.

The fruiting bodies of Pleurotus ostreatus are transient. Due to the high-water content (87-95\%), oyster mushrooms, like other mushrooms, cannot be stored for more than $24 \mathrm{~h}$ in the environment and 5-7 days after cooling, which requires rapid treatment [15].

Drying remains the most common method for the long-term preservation of mushrooms. Dehydration prevents the growth of microorganisms, reduces enzyme activity, slows down reactions in the presence of water and thus effectively preserves the positive properties of mushrooms and prolongs their shelf life [16]. However, due to various dehydration conditions and mechanisms, and the different composition and types of raw materials, the drying process may have a mixed influence on product properties [17]. Drying processes can influence not only the original properties and composition, but also the cell structure of the raw material and thus the release and bioavailability of substances from the food matrix $[18,19]$.

Certain drying methods can improve the quality, preservation, and even value of raw materials [20,21]. Others, however, may be accompanied by a significant decline [22,23]. Therefore, the technology for obtaining dry natural products must be developed separately for each type of raw material and based on experimental data on the influence of specific drying conditions on the specific properties of the final product. This is particularly important for mushroom raw materials with low resistance to mechanical and physical factors compared to plant material [24].

The most common applications in the food industry are lyophilic drying, hot air drying, microwave drying and sun drying. Each of the above drying methods has its own unique characteristics, but the comparative analysis of these methods is not sufficiently studied regarding their impact on the structural, physical, chemical and functional properties of Pleurotus ostreatus mushrooms. In particular, comparative publications on the influence of the mentioned drying methods on the antioxidant activity of fruit bodies of Pleurotus ostreatus with an emphasis on specific links in the process of free-radical oxidation, as well as on ACE-inhibiting properties are lacking.

Therefore, the aim of this study was to study and compare the effects of four different drying methods (lyophilic, hot air, microwave, and solar drying) on the structural properties, rehydration capacity, chemical composition with an emphasis on phenols, flavonoids, profile of secondary metabolites and peptides, antioxidant and ACE-inhibiting activity of Pleurotus ostreatus. For the first time, the use of different drying methods was aimed at selecting dehydration conditions that provide maximum antioxidant properties (antiradical scavenging activity, reducing power activity, ferric reducing ability, total antioxidant capacity, activity of inhibiting lipid oxidation) and ACE-inhibiting effect of Pleurotus ostreatus under conditions of experimental gastrointestinal digestion. 


\section{Materials and Methods}

\subsection{Raw Materials}

The subject of this study was a common oyster mushroom (Pleurotus ostreatus), strain NK35 (SYLVAN, Hungary, Dunaharaszti) from the 2019 harvest, cultivated under mushroom growing conditions in the Stavropol region. For the study, fruit bodies of the same size and maturity without mechanical damage were selected. The initial moisture content of the fresh oyster mushrooms selected for the study was $88.56 \pm 0.3 \%$.

\subsection{Chemicals}

Chemicals were obtained from the following sources: Pepsin from porcine gastric mucosa (activity 600-1800 U/mg), hydrochloric acid 37\%, sodium hydroxide $\geq 98 \%$ (Sigma-Aldrich, St. Louis, MI, USA), pancreatin (activity): Amylase 22,500 FIP E/g, lipase 22,500 FIP E/g, protease 1050 FIP E/g, AppliChem, Darmstadt, Germany), bile extract (millipore), petroleum ether $40-60{ }^{\circ} \mathrm{C}, \geq 90 \%$, formaldehyde, sulfanilic acid $99 \%$, peptone, picric acid $\geq 98.0 \%$, sodium carbonate 99.5\% (Sigma-Aldrich), D-(+)-glucose monohydrate (AppliChem); Folin-Denis reagent, gallic acid (Supelco); ethyl alcohol 96.0-97.2\%, aluminium chloride 99.9\%, sodium acetate $>99 \%$, quercetin, phosphate buffered saline solution $\left(\mathrm{pH} 7.2\left(25^{\circ} \mathrm{C}\right)\right.$, potassium ferrocyanide $\geq 98.8 \%$, trichloroacetic acid $\geq 99 \%$, iron chloride $\geq 99 \%$, ascorbic acid $\geq 99 \%$, 1,10-phenanthroline $\geq 99 \%$, ammonium ferric sulphate dodecahydrate 99\% (Sigma-Aldrich); antioxidant test kit (Institute of Bioorganic Chemistry, National Academy of Sciences of Belarus, Republic of Belarus); metmyoglobin, ABTS (2,2'-Azino-bis(3-ethylbenzothiazolin-6-sulphonic acid) diammonium salt), hydrogen peroxide solution 30 wt.- $(w / w) \%$. in $\mathrm{H}_{2} \mathrm{O}$, Trolox (6-hydroxy-2,5,7,8-tetramethylchroman-2-carboxylic acid $97 \%$, oleic acid $\geq 99 \%$, ammonium thiocyanate $\geq 97.5 \%$ (Sigma-Aldrich); N-Hippuryl-His-Leu hydrate-powder $\geq 98 \%$; ACE from rabbit lung $\geq 1.0$ units $/ \mathrm{mg}$; ethyl acetate $99.8 \%$; hippuric acid $98 \%$, formic acid $\sim 98 \%$, acetonitrile isocratic grade for liquid chromatography, $\alpha$-Cyano-4-hydroxycinnamic acid, trifluoroacetic acid >99\% (Sigma-Aldrich); standards for chemical research were obtained from Diaem (Moscow, Russia).

\subsection{Drying Process}

Before drying, the mushrooms were washed under running water at room temperature for $30 \mathrm{~s}$. The remaining water was removed with a paper towel. The entire mushroom was dried in four various ways: freeze drying (FD), hot air drying (HAD), microwave drying (MWD), and sun drying (SD).

In each experiment, $200 \mathrm{~g}$ of oyster mushrooms were dried. The drying process was carried out until a constant moisture content was achieved in the samples. The initial and final moisture content of the samples was measured with a moisture analyzer (MB 25, Ohaus Corporation, Parsippany, NJ, USA) with an accuracy of $0.001 \%$. The values were considered when selecting the automatic measuring option with a heating temperature of $100{ }^{\circ} \mathrm{C}$ and a measuring time of $5 \mathrm{~min}$.

The final moisture content of the mushrooms FD, HAD, MWD and SD was $3.85 \pm 0.1 \%, 7.75 \pm 0.1 \%$, $5.26 \pm 0.1 \%, 7.33 \pm 0.1 \%$.

The finished dry oyster samples were stored in hermetically sealed containers and stored in a dark place at a temperature no higher than $25^{\circ} \mathrm{C}$ for further analysis.

\subsubsection{Freeze Drying (FD)}

The first part of the mushrooms was frozen in the freezer (TEFCOLD SE-45, Viborg, Denmark) at $-40{ }^{\circ} \mathrm{C}$ for $72 \mathrm{~h}$. It was then dried in a LS-500 freeze dryer (Prointech, St Petersburg, Russia) with a sublimator and a vacuum station. The transparent lid of the drying chamber was covered with aluminium foil to prevent the degradation of antioxidants by light oxidation. 
The average operating pressure in the drying chamber reached 80.0-90.0 $\mathrm{Pa}$, the condenser temperature $-49.0-50.0^{\circ} \mathrm{C}$, the mushroom heating for the entire drying process did not exceed $30{ }^{\circ} \mathrm{C}$. The average drying time was $26-27 \mathrm{~h}$.

\subsubsection{Hot Air Drying (HAD)}

The second part of the mushrooms was dried at atmospheric pressure and temperature by $55{ }^{\circ} \mathrm{C}$ in a drying cabinet model FD 115 (Binder, Germany) with forced ventilation. The mushrooms in the dryer were placed in a layer on trays. Temperature and air velocity were kept constant at $50{ }^{\circ} \mathrm{C}$ and $1.3 \mathrm{~m} / \mathrm{s}$, respectively.

\subsubsection{Microwave Drying (MWD)}

One third of the mushrooms were dried in the microwave in the household (model WD 900 EL 23-2III, Erisson, Russia). The single-layer sample arrangement on the turntable ensured uniform heating. Microwave drying was performed at a power of $200 \mathrm{~W}$ for $40 \mathrm{~min}$.

\subsubsection{Sun Drying (SD)}

The fourth batch of mushrooms was placed in stainless steel dishes and dried in the open sun at an ambient temperature of $25 \pm 5^{\circ} \mathrm{C}$ and a relative humidity of $40 \pm 5 \%$ for 3 days (average $9 \mathrm{~h}$ per day).

\subsection{Determination of Structure and Rehydration Ratio}

\subsubsection{X-ray CT}

Volumetric structural properties of dry fruit bodies of the Pleurotus ostreatus were investigated by X-ray microtomography with an X-ray microcomputer tomography system Skyscan 1176 (Bruker, Kontich, Belgium). The study selected cylindrical fragments of Pleurotus ostreatus with a diameter of 6-7 mm and a length of 9-10 $\mathrm{mm}$, which were cut from the stem of the mushroom directly under the cap. The samples were scanned with the following parameters: X-ray voltage and current of $40 \mathrm{KV}$ and $600 \mu \mathrm{A}$ respectively; without filter; pixel size of $8.77 \mu \mathrm{m}$; scanning time of $60 \mathrm{~min}$. The scan protocol included a $180^{\circ}$ rotation at $0.3^{\circ}$ rotation. The exposure time is $535 \mathrm{~ms}$ per image, the image averaging is 4 .

The three-dimensional reconstruction of the samples was performed with the reconstruction software NRecon (version 1.7.1.0, Bruker, Kontich, Belgium). The following settings were used for the microtomographic reconstruction: without smoothing, correction of ring artefacts $=10 \%$ and correction of beam hardening $=51 \%$.

CTAn software was used for the quantitative analysis of the internal structure (version: 1.18.4.0, Bruker Kontich, Belgium). The internal structure of Pleurotus ostreatus samples of dried fruit bodies was characterized by the following microtomographic parameters used for food [25]: percent object volume (POV); objective surface-to-volume ratio (OSVR); fragmentation index (FI); degree of anisotropy (DA); structure modelling index (SMI).

\subsubsection{Determination of Rehydration Ratio (RR)}

RR of dried mushrooms was determined by immersing pre-weighed samples in distilled water ( $50 \mathrm{~mL}$ water per $1 \mathrm{~g}$ dry mushrooms) at room temperature. The mushrooms were then removed from the water and gently soaked with a paper towel to remove excess water from the surface. Mushroom samples were weighed on a ML203E precision scale (Mettler Toledo, Spain). The evaluation was carried out every 5 min until reaching the mass transfer equilibrium. Each rehydration experiment was repeated three times. RR were calculated using the formula [17]:

$$
\mathrm{RR}=\left(\mathrm{W}_{1}-\mathrm{W}_{0}\right) / \mathrm{W}_{0},
$$


where $\mathrm{W}_{1}$ and $\mathrm{W}_{0}$ are masses of rehydrated or dried oyster mushroom samples.

\subsection{In Vitro Digestion Methods}

Chemical characterization and study of the antioxidant properties of fruiting bodies of Pleurotus ostreatus, dried in various ways, were performed in vitro by simulating the process of gastrointestinal digestion, which was reproducible by the method of McDougall et al. [26] in some of its changes.

At $5 \mathrm{~g}$ lightly ground dried fruit bodies, $100 \mathrm{~mL}$ distilled water was added to the oyster mushrooms, then $33 \% \mathrm{HCl}$ solution up to $0.5 \%$ was added and the mixture incubated with $0.1 \%$ pepsin in $\mathrm{ES}$ 20/60 (Biosan, Latvia) thermal shaker for $120 \mathrm{~min}$ at $37^{\circ} \mathrm{C}$ at shaking temperature in $120 \mathrm{rpm}$ mode. Neutralized $1 \mathrm{M} \mathrm{NaOH}$ to $\mathrm{pH} 7.0$ (pH meter S400-B, Mettler Toledo, Spain), addition of a mixture of pancreatin $2 \mathrm{mg} / \mathrm{mL}$ and $4 \mathrm{~mL}$ bile extract, incubation in a thermoshaker for $120 \mathrm{~min}$ at $37^{\circ} \mathrm{C}$ and shaking $120 \mathrm{rpm}$. The extraction was stopped by boiling for $10 \mathrm{~min}$.

The extracts were centrifuged for $60 \mathrm{~min}$ at $8000 \mathrm{rpm}$ (centrifugal table Universal 320, Hettich, Germany).

After centrifugation, the sludge was separated, and petroleum ether was added to the supernatant (1:3). Mixed with a magnetic stirrer for $4 \mathrm{~h}$. The water and lipid fractions were separated in the separating funnel. All subsequent analyses were performed with the water fraction of the extract.

\subsection{Chemical Analysis of Oyster Mushroom Extracts}

\subsubsection{Determination of the Basic Chemical Parameters}

The degree of hydrolysis $(\mathrm{DH} \%)$ was determined by the AN/TN ratio in the final substance, where AN is the amount of amine nitrogen determined by the formaldehyde titration method [27], TN is the amount of total nitrogen determined by the Kjeldahl titrimetric method.

The dry mass was determined with the moisture analyzer Ohaus MB 25 (Ohaus Corporation, USA) in automatic mode at $100{ }^{\circ} \mathrm{C}$. Ionometry was performed with the $\mathrm{pH}$ meter S400-B (Mettler Toledo, Spain).

Peptide concentrations were determined by the biuret method [28] using $1 \%$ peptone solution as standard. The optical density of extract samples was measured at a wavelength of $540 \mathrm{~nm}$ with the UV spectrophotometer SF 102 (NPO INTERFOTOFIZIKA, Moscow, Russia).

The amount of sugar in extracts of dried mushrooms was spectrophotometrically determined by reaction with picric acid (Creselius-Seifert). In the interaction of reducing sugars with picric acid, they are oxidized to the corresponding acids, and the picric acid is returned to the red or brownish-red picric acid. For this purpose, $1 \mathrm{~mL}$ of saturated aqueous picric acid solution and $3 \mathrm{~mL}$ of sodium carbonate solution were added to $0.5 \mathrm{~mL}$ of the tested mushroom extracts, then the tube was transferred to a boiling water bath for $30 \mathrm{~min}$. Cool to room temperature and bring to $10 \mathrm{~mL}$ with distilled water. The optical density of the solution was determined at $455 \mathrm{~nm}$ (blue filter). The reducing sugar content was calculated from the calibration curve consisting of standard glucose solutions.

\subsubsection{Total Phenol Content (TPC)}

The total phenol content was measured with the Swain, \& Hillis method [29] with some modifications. Samples of the extracts obtained in a volume of $2.5 \mathrm{~mL}$ were mixed with $0.5 \mathrm{~mL}$ Folin Denis Reagent (F.D.R.). After 3 min $0.5 \mathrm{~mL}$ of $20 \%$ sodium carbonate solution were added. The total volume was increased to $10 \mathrm{~mL}$ with distilled water. The mixture was incubated in the dark for $90 \mathrm{~min}$. The optical density was then measured at $725 \mathrm{~nm}$ using the SF-102 spectrophotometer. Gauliensic acid was used to obtain a standard curve with a calibration range of $0-100 \mu \mathrm{g} / \mathrm{mL}\left(R^{2}=0.998\right)$ and the results were given in $\mathrm{mg}$ of the equivalent of Gauliensic acid (GAE) per $1 \mathrm{~g}$ mushroom per dry weight (mg GAE/g). 


\subsubsection{Total Flavonoid Content (TFC)}

The content of flavonoids was determined using the colorimetric method described by Chia-Chi et al. [30] in some modifications. $0,5 \mathrm{~mL}$ mushroom extract were selected and mixed with $1.5 \mathrm{~mL}$ $95 \%$ ethanol, $0.1 \mathrm{~mL} 10 \%$ aluminium chloride, $0.1 \mathrm{~mL} 1 \mathrm{M}$ sodium acetate and $2.8 \mathrm{~mL}$ distilled water. This mixture was incubated at room temperature for $30 \mathrm{~min}$ in the dark. The optical density was measured at $415 \mathrm{~nm}$. Quercetin was used to obtain a standard curve with a calibration range of $0-100 \mu \mathrm{g} / \mathrm{mL}$ and the flavonoid content was calculated in $\mathrm{mg}$ quercetin equivalent per gram of dried sample (mg QE/g).

\subsubsection{Gas Chromatographic Analysis}

The composition of the secondary metabolites was investigated using a gas chromatograph Agilent 6850 (Agilent Technologies, Moscow, Russia) with a mass detector Agilent 5975V. The percentage composition of the secondary metabolites was calculated using peak ranges without the use of correction factors. Qualitative analysis was based on the comparison of mass spectra of substances with the corresponding data of the NIST0.5a mass spectra library.

\subsubsection{Matrix-Assisted Laser Desorption/Ionization (MALDI) Time-of-Flight (TOF) Mass Spectrometry}

Analysis of the peptide profile of the extracts was performed using MALDI-TOF mass spectrometry. The extracts were centrifuged at 10,000 rpm for 4 min (MiniSpin microcentrifuge (Eppendorf AG, Hamburg, Germany). The supernatant (1 microliters) was deposited on the plate. Pretreated and untreated samples were overlaid with 1 microliters of matrix solution (saturated solution of a-cyano-4-hydroxycinnamic acid in 50\% acetonitrile and $2.5 \%$ trifluoroacetic acid). The matrix sample was cocrystallized by air drying at room temperature. Measurements were performed with a Microflex mass spectrometer (Bruker Daltonik, Bremen, Germany) using Daltonics FlexControl software (version 3.3.64, Bruker Daltonik, Bremen, Germany). Spectra were recorded in the positive linear mode (laser frequency, $60 \mathrm{~Hz}$; ion source 1 voltage, $19.4 \mathrm{kV}$; ion source 2 voltage, $17.3 \mathrm{kV}$; lens voltage, $8.0 \mathrm{kV}$; mass range, 0 to 20,000 dalton (Da)). For each spectrum 4000 shots from different positions of the target spot (automatic mode) were collected and analyzed. Protein identification was performed using the BIOPEP-UWM database [31].

\subsection{Determination of Antioxidative Activity}

\subsubsection{ABTS Radical Scavenger Activity}

The ABTS radical scavenger activity was determined with a set of reagents to quantify the antioxidant activity of FITCHEM (Belarus) with some modifications. A chromogen was prepared by mixing the solutions (metmyoglobin $(5 \mathrm{~mL}, 2.8 \mu \mathrm{M})$ dissolved in $5 \mathrm{~mL}$ phosphate buffer $(50 \mathrm{mM}$, $\mathrm{pH} 7.4$ ) and ABTS (2,2-azino-bis-[3-ethylbenzthiazolin-6-sulfonic acid]-diammonium salt, $5 \mathrm{~mL}, 546$ $\mu \mathrm{M}$ ) dissolved in $5 \mathrm{~mL}$ phosphate buffer). Add $0.9 \mathrm{~mL}$ chromogen, $0,3 \mathrm{~mL}$ substrate (hydrogen peroxide $(0.88 \mathrm{mM})$ to $0,45 \mathrm{~mL}$ phosphate buffer $(50 \mathrm{mM}, \mathrm{pH} 7,4)$ and incubate for $3 \mathrm{~min}$. $0.02 \mathrm{~mL}$ sample was added to the resulting solution and kept for $10 \mathrm{~min}$. Absorption was measured at $735 \mathrm{~nm}$. A solution of Trolox (6-hydroxy-2,5,7,8-tetramethylchroman-2-carboxylic acid) was used as standard. In the negative control, distilled water was used instead of extract. The ABTS method was determined with a UV spectrophotometer SF 102.

\subsubsection{Reduction of Performance Activity}

The analysis was performed using the method described by Klompong et al. [32], based on the principle of increasing the absorption of reaction mixtures. The extract in the volume of $0.2 \mathrm{~mL}$ of each sample was mixed with $2 \mathrm{~mL}$ phosphate buffer $(0.2 \mathrm{M}$, pH 6.6) and $5 \mathrm{~mL} 1 \%$ potassium hexacyanoferrate. After incubation at $50{ }^{\circ} \mathrm{C}, 1 \mathrm{~mL}$ of $10 \%$ trichloroacetic acid was added for $20 \mathrm{~min}$ and after shaking, the 
solution was centrifuged for $10 \mathrm{~min}$ with a centrifuge (MicroCL 17R, Thermo, Germany) at 2000× $g$. The solution was then mixed with $1 \mathrm{~mL}$ of trichloroacetic acid for $20 \mathrm{~min}$. The supernatant was mixed with $2 \mathrm{~mL}$ distilled water and $0.5 \mathrm{~mL} 0.1 \%$ ferric chloride. After incubation at room temperature, the optical density at $700 \mathrm{~nm}$ was measured with an SF-102 UV spectrophotometer for $10 \mathrm{~min}$. The higher absorption indicates a higher regenerability. Ascorbic acid solution $(1 \mathrm{mg} / \mathrm{mL})$ was a positive control.

\subsubsection{Ferri Reducibility (the FRAP Assay)}

For FRAP analysis, a complex reagent was prepared by dissolving $0.1980 \mathrm{~g}$ 1,10-phenantroline in 30-40 mL distilled water at low heat and $0.2892 \mathrm{~g}$ iron-ammonium aluminium with $2 \mathrm{~mL}$ hydrochloric acid $\left(1 \mathrm{~mol} / \mathrm{dm}^{3}\right)$ in $30-40 \mathrm{~mL}$ distilled water at low heat for $0.1980 \mathrm{~g}$ 1,10-phenantroline. The solutions obtained were mixed and the volume increased to $100 \mathrm{~mL}$ with distilled water. The prepared reagent was kept for $12 \mathrm{~h}$. Add $2 \mathrm{~mL}$ of the complex reagent by $0.02 \mathrm{~mL}$ of the extract sample and increase the total volume to $50 \mathrm{~mL}$ with distilled water. The mixture was stirred and after $60 \mathrm{~min}$ the optical density was measured at a wavelength of $490 \mathrm{~nm}$ in cells with an optical path length of $10 \mathrm{~mm}$ relative to the distilled water. Ascorbic acid solution $(1 \mathrm{mg} / \mathrm{mL})$ was a positive control.

\subsubsection{Determination of Total Antioxidant Capacity by Electrochemical Method}

The total antioxidant capacity was determined by the electrochemical method to correspond to Piljac-Žegarac et al. [33], and Hoyos-Arbelaez et al. [34]. The total antioxidative capacity was determined using the "Tsvet-Yauza-01-AA" liquid chromatograph with amperometric detection (Russia). Gallic acid solution was used as reference substance. Amperometrically, the method is based on measuring the strength of the electric current generated by oxidation of the antioxidant molecules on the working electrode surface at a certain potential, which is converted into a digital signal after amplification. During the analysis, a calibration curve for 5 consecutive measurements of 5 calibration solutions of Gallic acid is prepared. The result is the arithmetic mean of 5 measurements. Based on the obtained data, a calibration diagram is created, which is described by the equation:

$$
\mathrm{Y}=\mathrm{aX}+\mathrm{b}
$$

The calibration diagram is then calculated from the calibration solutions. In the coordinates: $\mathrm{X}$ is the mass concentration of gallic acid, $\mathrm{mg} / \mathrm{L} ; \mathrm{Y}$ is the signal of gallic acid (peak area), $\mathrm{nA} / \mathrm{s}$.

\subsubsection{Lipid Peroxidation Inhibition Test}

The activity of lipid peroxidation inhibition was measured in the oleic acid emulsion system using the method described by Kimatu et al. [35] in some changes. To $4.0 \mathrm{~cm}^{3}$ phosphate buffer $(50 \mathrm{~mm}$, pH 7.0) $0.1 \mathrm{~cm}^{3}$ extract and $0.1 \mathrm{~cm}^{3}$ oleic acid were added to $4.0 \mathrm{~cm}^{3}$ ethanol (95 wt.\% water solution). The total volume was brought to $10.0 \mathrm{~cm}^{3}$ by distilled water, mixed in a hermetically sealed conical tube with screw cap and incubated for 7 days at $40{ }^{\circ} \mathrm{C}$ in the dark. The degree of oxidation was estimated by iron thiocyanate at $24-\mathrm{h}$ intervals. The reaction solution $(100 \mu \mathrm{L})$ was mixed with $4.7 \mathrm{~cm}^{3}$ ethanol (75 wt. \%, aqueous solution), $0.1 \mathrm{~cm}^{3}$ ammonium thiocyanate (30\% wt. \%) and $0.1 \mathrm{~cm}^{3}$ ferric chloride (II) $(2 \mathrm{mM}$ in $3.5 \%$ (vol./r) HCl). After $3 \mathrm{~min}$ the absorption capacity at a wavelength of $500 \mathrm{~nm}$ was measured with a UV spectrophotometer. The increase of the optical density meant an increase of the degree of oxidation of the oleic acid. Trolox $\left(0.95 \mathrm{mmol} / \mathrm{dm}^{3}\right)$ was used as a reference for the investigated activity. In the blank, deionized water was used instead of extract.

\subsection{Angiotensin-Converting Enzyme Assay (ACE) Inhibitory Assay}

The ACE inhibitory activity assay was performed according to the method by Abdullah et al. [36] with some modifications. Briefly, $200 \mu \mathrm{L}$ of $5 \mathrm{mM}$ hippuryl-L-histidine-L-leucine (HHL) (Sigma) solution was mixed with $50 \mu \mathrm{L}$ of each mushroom extract and the mixture was preincubated at $37^{\circ} \mathrm{C}$ for $3 \mathrm{~min}$. The reaction was initiated by the addition of $20 \mu \mathrm{L}$ of $0.1 \mathrm{U} / \mathrm{mL}$ ACE (Sigma) solution and the mixture 
was again incubated at $37^{\circ} \mathrm{C}$ for $30 \mathrm{~min}$. The reaction was terminated with the addition of $250 \mu \mathrm{L}$ of $1 \mathrm{~N} \mathrm{HCl}$. Then, $1.5 \mathrm{~mL}$ of ethyl acetate was added to extract the hippuric acid liberated by the reaction. The solution was centrifuged for $10 \mathrm{~min}$; the ethyl acetate layer was then aspirated and evaporated under vacuum condition. The dried hippuric acid was re-dissolved in $1 \mathrm{~mL}$ of distilled water and measured spectrophotometrically at $228 \mathrm{~nm}$. The ACE inhibitory activity of the mushroom extracts was determined by the following equation:

$$
\text { Percentage of inhibition }(\%)=\frac{B-A}{B-C} \times 100 \text {, }
$$

where $\mathrm{A}$ is the absorbance of ACE and mushroom extracts, B is the absorbance of ACE and HHL, and $\mathrm{C}$ is the absorbance of HHL only.

\subsection{Statistical Analysis}

All statistical analyses were performed with GraphPad Prism for Windows, Version 6.01 (GraphPad Software, San Diego, CA, USA). The statistical analysis was performed by a one-way variance analysis (ANOVA). $p<0.05$ was considered statistically significant. The results were expressed as mean \pm SD $(n=3)$.

\section{Results and Discussion}

It is well known that chromaticity is one of the criteria for the quality of a dry product, the modification of which is due to pigment degradation and enzymatic darkening during drying [37]. Visually lyophilic dried oyster mushrooms have the same colour as fresh mushrooms (Figure 1).

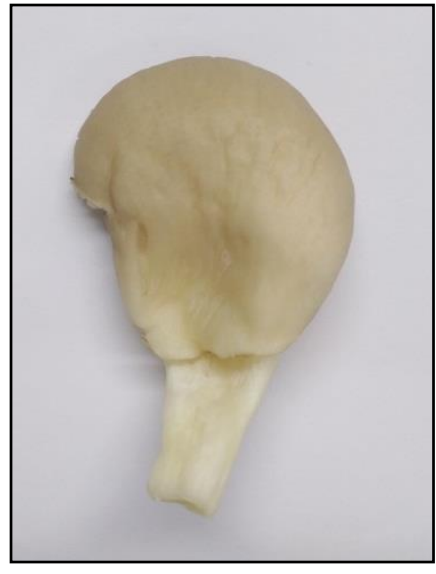

(a)

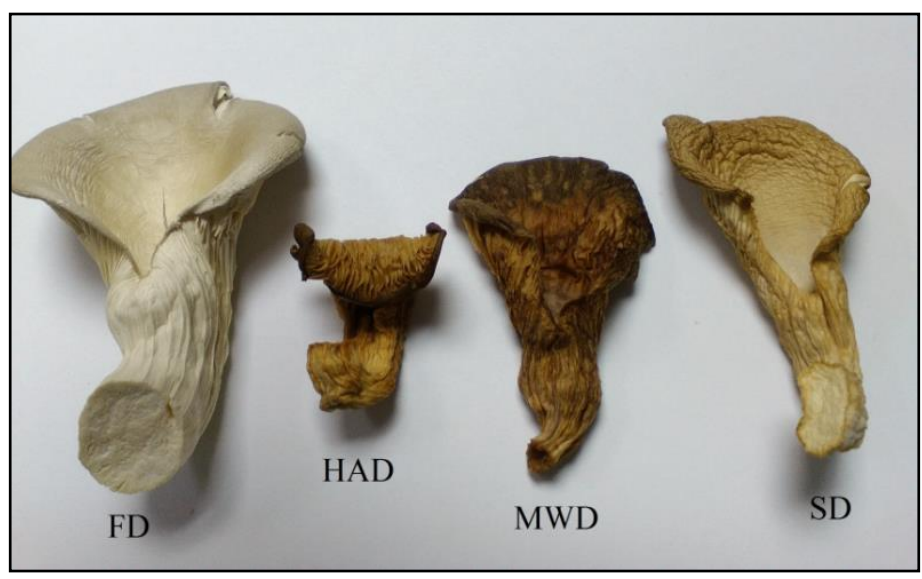

(b)

Figure 1. Macroscopic photos of fresh oyster mushroom (a) and after drying (b) FD—freeze drying; HAD—hot air drying; MWD—microwave drying; SD—sun drying.

Dried mushrooms were distributed in the following order of color intensity in the order of their increase: $\mathrm{FD}<\mathrm{SD}<\mathrm{HAD}<\mathrm{MWD}$.

The low colour intensity of FD samples can be explained by the low oxygen concentration in the vacuum range of the lyophilic dryer and thus by the lower intensity of the enzymatic reactions, which are the main cause of the discoloration of dried mushrooms [16]. Darker staining of MWD and HAD samples may be due to the reaction of saccharoamine condensation (Maillard reaction) during heating, as mentioned by Izli \& Isik [38]. 


\subsection{X-ray CT Analysis}

It is known that drainage conditions influence the structure of the final product. Using X-ray microtomography it was reported that freeze-dried mushrooms had uniform pore volume distribution. Dry-air dehydration method lead to the formation of larger cavities [39]. Structural changes can influence the process of mass and heat transfer, accompanied by biochemical changes, as well as the degree of release of bioactive substances from the food matrix [40]. In this context, in order to fully understand the influence of the conditions of the investigated drying methods on the antioxidative properties of Pleurotus ostreatus, the structure of dry mushrooms was investigated by X-ray microtomography.

Figure 2 shows microtomographic images of dry oyster mushroom cross sections. The obtained 3D models of mushroom samples show the spatial distribution of X-rays, with brighter areas corresponding to a higher density and darker areas to cavities.

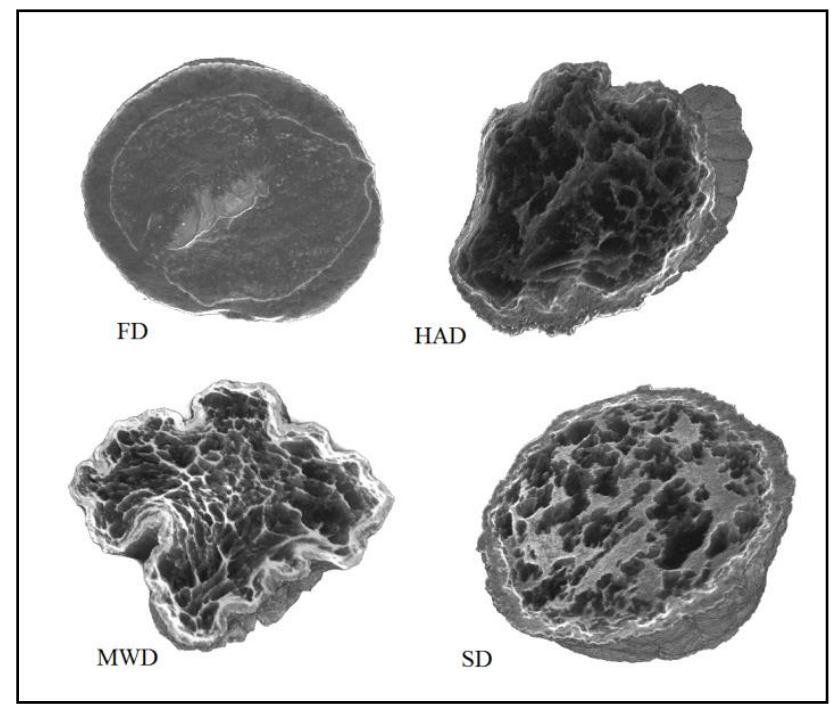

Figure 2. X-ray microtomography images of mushroom samples after drying. FD—freeze drying; HAD—hot air drying; MWD—microwave drying; SD—sun drying.

The microtomographic images show that all samples of dry mushrooms are heterogeneous in structure and number of pores. There is an increase in voids in the direction of FD $<\mathrm{SD}<\mathrm{MWD}$ $<$ HAD.

Table 1 shows average values and results of statistical analysis of microstructural parameters of dry coat of arms samples obtained with the CTAn software (Skyscan, Kontich, Belgium).

Table 1. Microtomographic parameters of the fruit bodies of Pleurotus ostreatus, dried in various ways.

\begin{tabular}{cccccc}
\hline & POV $^{\mathbf{1}}$ & OSVR $^{\mathbf{2}}$ & FI $^{\mathbf{3}}$ & DA $^{\mathbf{4}}$ & SMI $^{\mathbf{5}}$ \\
\hline FD & $87.14 \pm 3.78^{\mathrm{a}}$ & $0.015 \pm 0.00067^{\mathrm{a}}$ & $-0.08 \pm 0.0034^{\mathrm{a}}$ & $0.26 \pm 0.010^{\mathrm{a}}$ & $-32.08 \pm 1.39^{\mathrm{a}}$ \\
HAD & $72.34 \pm 3.20^{\mathrm{b}}$ & $0.019 \pm 0.00081^{\mathrm{b}}$ & $0.000029 \pm 0.0000012^{\mathrm{b}}$ & $0.37 \pm 0.016^{\mathrm{b}}$ & $0.009 \pm 0.00034^{\mathrm{b}}$ \\
MWD & $56.76 \pm 2.53^{\mathrm{c}}$ & $0.018 \pm 0.00077^{\mathrm{b}}$ & $0.00082 \pm 0.00034^{\mathrm{c}}$ & $0.55 \pm 0.024^{\mathrm{a}}$ & $0.27 \pm 0.012^{\mathrm{c}}$ \\
SD & $59.93 \pm 2.58^{\mathrm{c}}$ & $0.021 \pm 0.0011^{\mathrm{b}}$ & $-0.014 \pm 0.00060^{\mathrm{d}}$ & $0.34 \pm 0.014^{\mathrm{b}}$ & $-0.38 \pm 0.016^{\mathrm{d}}$ \\
\hline
\end{tabular}

Different superscript letters indicate statistically significant differences between the means $(p<0.05)$ for each parameter. ${ }^{1}$ Percent object volume; ${ }^{2}$ Object surface/volume ratio; ${ }^{3}$ Fragmentation index; ${ }^{4}$ Degree of anisotropy; ${ }^{5}$ Structure modeling index. FD—freeze drying; HAD—hot air drying; MWD—microwave drying; SD—sun drying.

The POV is calculated as the average percentage of pores inside the object. According to the table, the FD samples have the maximum POV value (highest porosity). MWD and SD samples have the lowest POV values. 
With respect to the FI index, the structural cohesion index and the measure of relative convexity or concavity of the total pore surface, the FD and SD samples were characterized by negative values of this parameter. This indicates that a large part of their structure is open, cross-linked pores. The HAD and MWD samples had positive FI values, confirming the presence of a high percentage of closed, clearly separated pores in their structure.

The degree of anisotropy (DA) is an indicator of three-dimensional structural symmetry, which in this case indicates the presence or absence of a preferred pore orientation of the samples in several direction [41]. A value of 0 corresponds to full isotropy, a value of 1 corresponds to total anisotropy. According to the mentioned parameters, MWD samples are significantly differentiated, which are characterized by maximum values of DA and SMI parameters. The above mentioned changes quantitatively confirm the higher deformation of the MS mushroom compared to other samples and are consistent with the materials of Apati et al. [42] which states that high drying temperatures lead to an increase in the water release rate and thus to a significant deformation of the structure of mushrooms.

Thus, various drying mechanisms of Pleurotus ostreatus fruit bodies have a very different influence on the microstructural properties of the dry product. X-ray microtomography and the obtained data of the three-dimensional microstructure of dried mushrooms proved to be useful tools. Such a plan to identify the internal structure is important as changes in microstructural relationships can influence the physicochemical, nutritional, and functional properties of the product from a range of data [19].

\subsection{Effects of Drying Methods on the Rehydration Ratio}

Microtomographically recorded structural differences between samples of dry fruit bodies of Pleurotus ostreatus were combined with different manifest rehydration properties, which represent a kind of measure of structural damage to the product in the dehydration process (Figure 3).

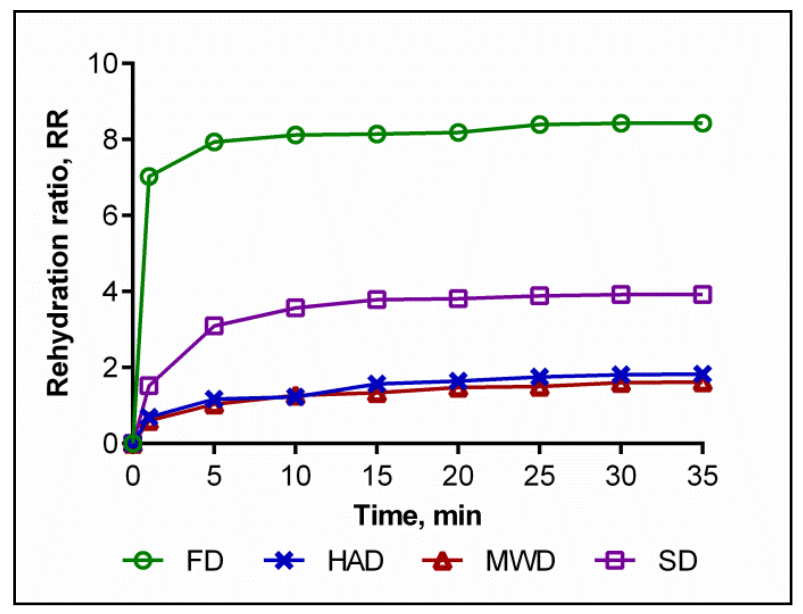

Figure 3. Rehydration curves of dried oyster mushrooms at distinct time. FD—freeze drying; HAD—hot air drying; MWD—microwave drying; SD—sun drying.

The RR values of FD mushrooms were found to be maximum and significantly higher than those of other samples. Similar results were found in previous studies [39] and are explained by the above structural differences in dry oyster mushroom samples.

The RR samples of HAD and MWD were relatively low and did not differ significantly. The ability to rehydrate SD samples was mediocre. Similar data are available in the countries of Singh and Pandey [43] or Seremet et al. [44] and may be caused by the structural collapse of tissues and the formation of hard layers in the process of product dehydration to prevent rehydration.

Thus, the conditions of FD and SD may provide a higher rehydration capacity of the dry oyster mushroom product compared to HAD and MWD and thus contribute to shortening the cooking 
time of mushrooms, facilitating their incorporation and improving the efficiency of the extraction of biologically active substances.

\subsection{Influence of Drying Processes on Some Chemical Properties of Pleurotus Ostreatus under In Vitro} Conditions Simulating the Gastrointestinal Digestive Process

\subsubsection{Basic Chemical Parameters}

The net efficacy of food-borne bioactive substances depends on their actual content and activity in the digestive tract [45]. Therefore, a full assessment of the biologically active properties of foods or their ingredients should be carried out under digestive conditions.

The dry mushroom samples we examined were exposed to reactions that mimic the gastrointestinal digestive process. The basic physicochemical parameters characterizing the extracts obtained under these conditions are listed in Table 2.

Table 2. Some physicochemical parameters of the dry fruiting bodies of Pleurotus ostreatus after in vitro digestion.

\begin{tabular}{ccccc}
\hline The Investigated Parameter & FD & HAD & MWD & SD \\
\hline Amount of dry matter, g/L & $40.0 \pm 1.73^{\mathrm{a}, \mathrm{b}}$ & $37.3 \pm 1.61^{\mathrm{a}}$ & $43.3 \pm 1.92^{\mathrm{b}}$ & $39.9 \pm 1.82^{\mathrm{a}, \mathrm{b}}$ \\
Ionometry (pH) & $7.05 \pm 0.31^{\mathrm{a}}$ & $6.91 \pm 0.29$ & $7.5 \pm 0.33$ & $6.93 \pm 0.31$ \\
Total nitrogen (TN), $\%$ & $0.27 \pm 0.01^{\mathrm{a}}$ & $0.20 \pm 0.01^{\mathrm{a}}$ & $0.32 \pm 0.01^{\mathrm{b}}$ & $0.22 \pm 0.01^{\mathrm{a}}$ \\
Amine nitrogen (AN), g/L & $0.87 \pm 0.04^{\mathrm{a}}$ & $0.95 \pm 0.04^{\mathrm{a}, \mathrm{c}}$ & $0.80 \pm 0.04^{\mathrm{b}}$ & $1.01 \pm 0.04^{\mathrm{c}}$ \\
Degree of hydrolysis (DH), $\%$ & $32.1 \pm 1.56^{\mathrm{a}}$ & $46.7 \pm 2.08^{\mathrm{b}}$ & $25.1 \pm 1.21^{\mathrm{c}}$ & $45.8 \pm 2.08^{\mathrm{b}}$ \\
Amount of amino acids, g/L & $3.81 \pm 0.17^{\mathrm{a}}$ & $4.16 \pm 0.18^{\mathrm{b}}$ & $3.51 \pm 0.15^{\mathrm{a}}$ & $4.02 \pm 0.19^{\mathrm{b}}$ \\
Amount of peptides, g/L & $8.06 \pm 0.35^{\mathrm{a}}$ & $4.73 \pm 0.21^{\mathrm{b}}$ & $10.46 \pm 0.45^{\mathrm{c}}$ & $5.23 \pm 0.21^{\mathrm{b}}$ \\
Amount of monosaccharides & & & & \\
$\quad$ in recalculation for & $0.24 \pm 0.01^{\mathrm{a}}$ & $0.21 \pm 0.01^{\mathrm{a}}$ & $0.23 \pm 0.01^{\mathrm{a}}$ & $0.22 \pm 0.01^{\mathrm{a}}$ \\
$\quad$ glucose, $\%$ & & & \\
\hline Different superscript letters indicate statistically significant differences between the means $(P<0.05)$ for each $^{\text {a }}$
\end{tabular}

Different superscript letters indicate statistically significant differences between the means $(P<0.05)$ for each parameter. FD-freeze drying; HAD-hot air drying; MWD-microwave drying; SD-sun drying.

According to the tabular data for amino acids the extract samples were distributed as follows in order to increase their quantity: MWD $<\mathrm{FD}<\mathrm{HAD}<\mathrm{SD}$. The maximum degree of hydrolysis was characterized by HAD mushrooms, the minimum, MWD. The number of peptides was leading in MWD extracts. The order of decrease of peptide concentration in the rest of the samples looked like this: $\mathrm{FD}>\mathrm{SD}>\mathrm{HAD}$.

On the one hand, these values show that the conditions of HAD and SD, characterized by a prolonged process of dehydrogenation and possible reactions of autohydrolysis of proteins in the department with the subsequent conditions of simulated process of gastrointestinal digestion, offer a more complete proteolysis of proteins of mushroom tissue. On the other hand, there is evidence of the accumulation of peptides in FD and MWD samples which, according to Sun et al. [46], may provide a high antioxidant effect of Pleurotus ostreatus dried fruit extracts.

\subsubsection{Effects of Drying Processes on the TPC and TFC of Oyster Mushroom Extracts}

Phenolic compounds are one of the most important groups of secondary metabolites of mushrooms with proven antioxidant properties [47].

The results showed that, in the gastrointestinal digestive model, MWD samples had the highest TPC values in vitro, followed by HAD, SD and FD samples. This is clearly shown in Figure 4. 


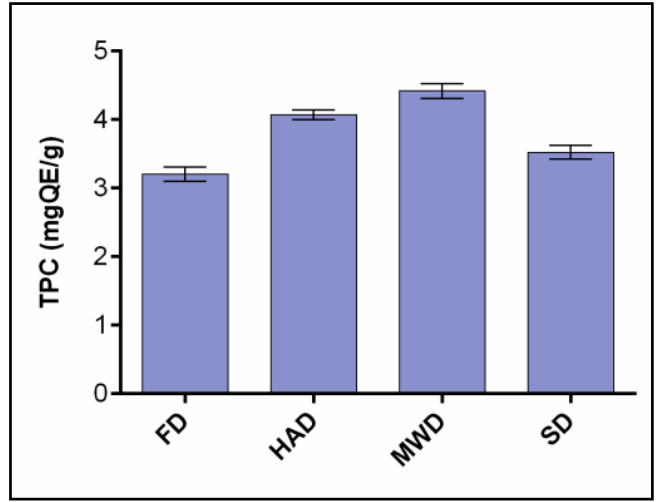

(a)

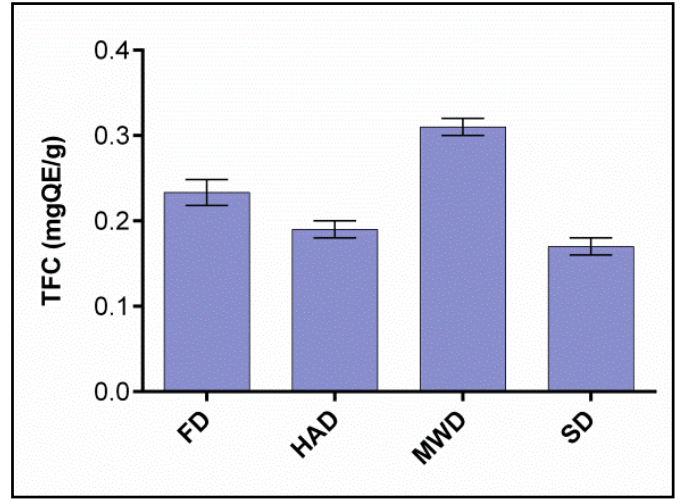

(b)

Figure 4. The content of total phenols (a) and total flavonoids (b) in the dry fruit bodies of Pleurotus ostreatus after in vitro digestion. FD—freeze drying; HAD—hot air drying; MWD—microwave drying; SD—sun drying.

The results obtained to some extent contradict the data from Lim, \& Murtijaya [48], according to which intensive and rapid heating during microwave drying can lead to severe thermal degradation of phenolic compounds. It is also known that phenolic substances are found at the cellular level in vacuoles and are separated from oxidative enzymes in intact tissues [49]. Microwave drying is associated with the destruction of the cell structure of mushrooms and leads to the release of oxidative and hydrolytic enzymes and thus to the destruction of phenols.

The ambiguity of the results shown by us can be quite logical. Many researchers [50] have noticed that the TPC content in different plant objects changes differently under various drying conditions. The drying process can lead to high or low TPC values depending on the type of plant material and the localization of the phenolic compounds present in the cell.

In our case, the maximum TPC value in MWD samples is probably determined both by high temperatures, which according to Dewanto et al. [51] can deactivate destructive enzymes, and by the best extraction of phenolic acids from mushroom tissue destroyed by microwave radiation. For example, Kubra and Rao [52] combine the increase of TPC in dried MWD plant products with microwave energy, leading to the degradation of cell components and the release of polyphenols from matrices.

The loss of TPC in SD and FD mushroom samples can be caused by both enzymatic and non-enzymatic reactions of phenolic compounds during prolonged drying [53]. Low freeze-drying and solar drying temperatures are not capable of inactivating oxidative enzymes, which can lead to relatively low TPC values in FD and SD samples.

Samples of Pleurotus ostreatus dried fruit extracts by number of flavonoids (TFC) were distributed MWD-FD-HAD-SD in the following order.

Contrary to our assumption that low-oxygen and low-temperature FD media could effectively minimize flavonoid losses, the maximum TFC was recorded in MWD sample extracts. This is confirmed by the information provided by Toor and Savage [49] that the permeability of microwave radiation destroys the cellular components of tissue, making flavonoids more accessible for extraction. In addition, the relatively short heating time of microwave drying is more advantageous for the preservation of flavonoids than that of hot air drying.

The lowest TFC values were recorded in SD samples. This is most likely related to the duration of the drying and thus to the oxidation processes, which has been repeatedly observed in the works of Lacramioara et al. [54] in their investigation of dehydrogenation processes in plants.

\subsubsection{Composition of Secondary Metabolites}

Gas chromatography with mass spectroscopy was used to investigate the composition of secondary metabolites in dry oyster mushroom extracts. 
The chromatographic profile of the main substances identified, whose presence and content reflect the differences between the investigated samples of dry Pleurotus ostreatus mushroom extracts, is shown in Table 3.

Table 3. Profile of secondary metabolites of dry fruiting bodies Pleurotus ostreatus (based on the results of gas chromatography-mass-spectroscopy) after in vitro digestion.

\begin{tabular}{|c|c|c|c|c|c|}
\hline \multirow{2}{*}{ Name of the Compounds } & \multirow{2}{*}{ Structure } & \multicolumn{3}{|c|}{ Relative Peak Area (\%) } & \multirow[b]{2}{*}{ FD } \\
\hline & & FD & HAD & MWD & \\
\hline L-Lactic acid & & 48.72 & 22.24 & 27.23 & 28.81 \\
\hline $\begin{array}{l}\text { Butanedioic acid, 2,3-dihydroxy- } \\
{\left[R-\left(R^{*}, R^{*}\right)\right]-\text {, dimethyl ester }}\end{array}$ & & nd & 0.17 & 1.79 & nd \\
\hline Glycerin & & 6.10 & 2.08 & 3.15 & 2.08 \\
\hline 6-Nitrohexan-2-ol & & nd & 1.14 & nd & nd \\
\hline $\begin{array}{c}\text { 1-Butanamine, } \\
\text { 3-methyl-N-(3-methylbutylidene)- }\end{array}$ & & nd & nd & 1,23 & nd \\
\hline Cyclopentane, 1-acetyl-1,2-epoxy- & & nd & nd & 1,11 & nd \\
\hline $\begin{array}{l}\text { 1-Propanol, 2-(2- } \\
\text { hydroxypropoxy)- }\end{array}$ & & 2.19 & 1.65 & 2.88 & 1.61 \\
\hline 2-Propanol, 1,1'-oxybis- & & 1.19 & 1.11 & 2.2 & 0.96 \\
\hline Propanamide, $N$-methyl-2-amino- & & nd & nd & nd & 1.49 \\
\hline Benzeneethanamine & & 2.14 & 1.72 & nd & 1.92 \\
\hline Butanedioic acid, monomethyl ester & & 0.98 & 0.61 & 14.78 & 0.87 \\
\hline
\end{tabular}


Table 3. Cont.

\begin{tabular}{|c|c|c|c|c|c|}
\hline \multirow{2}{*}{ Name of the Compounds } & \multirow{2}{*}{ Structure } & \multicolumn{3}{|c|}{ Relative Peak Area (\%) } & \multirow[b]{2}{*}{ FD } \\
\hline & & FD & HAD & MWD & \\
\hline & & & & & \\
\hline 2(3H)-Furanone, dihydro-4-hydroxy- & & nd & nd & 1.24 & nd \\
\hline Ornithine & & 3.09 & 6.74 & nd & 2.85 \\
\hline Benzeneacetic acid & & nd & 4.56 & nd & 0.45 \\
\hline DL-Valine & & nd & nd & nd & 1.99 \\
\hline Alanine & & nd & 5.31 & nd & nd \\
\hline $\begin{array}{l}\text { 1,3-Dimethyl-3,4,5,6-tetrahydro- } \\
\text { 2(1H)-pyrimidinone }\end{array}$ & & 1.38 & nd & nd & nd \\
\hline D-Leucine & & 0.65 & 7.26 & nd & 2.54 \\
\hline $\begin{array}{c}\text { 2-Dimethyl } \\
\text { silyloxytetradecane }\end{array}$ & & nd & nd & nd & 5.3 \\
\hline d-Mannitol,1,4-anhydro- & & nd & nd & nd & 7.52 \\
\hline Uracil & & 0.37 & 4.12 & nd & nd \\
\hline $\begin{array}{l}\text { 1,3-Dimethyl-3,4,5,6-tetrahydro- } \\
\text { 2(1H)-pyrimidinone }\end{array}$ & & 1.58 & nd & nd & 1.67 \\
\hline $\begin{array}{c}\text { 4H-Pyran-4-one, } \\
\text { 2,3-dihydro-3,5-dihydroxy-6-methyl- }\end{array}$ & & nd & nd & 2.89 & nd \\
\hline
\end{tabular}


Table 3. Cont.

\begin{tabular}{|c|c|c|c|c|c|}
\hline \multirow{2}{*}{ Name of the Compounds } & \multirow{2}{*}{ Structure } & \multicolumn{3}{|c|}{ Relative Peak Area (\%) } & \multirow[b]{2}{*}{ FD } \\
\hline & & FD & HAD & MWD & \\
\hline $\begin{array}{l}\text { 1-Acetyl-4-piperidinecarboxylic } \\
\text { acid }\end{array}$ & & nd & 2.0 & nd & nd \\
\hline DL-Phenylalanine & & nd & 3.3 & nd & nd \\
\hline DL-Proline,5-oxo- & & 4.01 & 2.68 & 1.64 & 4.28 \\
\hline $\begin{array}{l}\text { Adenosine } 3^{\prime}, 5^{\prime} \text {-cyclic } \\
\text { monophosphate }\end{array}$ & & nd & nd & 2.71 & 2.67 \\
\hline $\begin{array}{l}\text { 4-Cyanobenzoic acid, } \\
\text { 2-phenylethyl ester }\end{array}$ & & nd & nd & nd & 1.19 \\
\hline $\begin{array}{l}N \text {-(gamma-L-Glutamyl) } \\
\text { phenylalanine }\end{array}$ & & 3.38 & nd & nd & nd \\
\hline $\begin{array}{l}\text { 3-Methyl-1,4-diazabicyclo [4.3.0] } \\
\text { nonan-2,5-dione, } N \text {-acetyl- }\end{array}$ & & 1.28 & nd & nd & 0.94 \\
\hline dl-Alanyl-1-leucine & & 1.03 & 3.74 & nd & 1.71 \\
\hline $\begin{array}{l}\text { Pyrrolo [1,2-a] pyrazine-1,4-dione, } \\
\text { hexahydro-3-(2-methylpropyl)- }\end{array}$ & & 3.19 & 2.68 & 2.59 & 5.49 \\
\hline $\begin{array}{c}\text { 5,10-Diethoxy-2,3,7,8-tetrahydro- } \\
\text { 1H,6H-dipyrrolo[1,2-a:1',2'-d] } \\
\text { pyrazine }\end{array}$ & & 2.29 & 1.89 & 1.65 & 1.0 \\
\hline $\begin{array}{l}\text { 2,4-Imidazolidinedione, } \\
\text { 5-(4-hydroxybutyl)- }\end{array}$ & & nd & 0.53 & nd & 1.11 \\
\hline
\end{tabular}


Table 3. Cont.

\begin{tabular}{|c|c|c|c|c|c|}
\hline \multirow{2}{*}{ Name of the Compounds } & \multirow{2}{*}{ Structure } & \multicolumn{3}{|c|}{ Relative Peak Area (\%) } & \multirow[b]{2}{*}{ FD } \\
\hline & & FD & HAD & MWD & \\
\hline n-Hexadecanoic acid & & 2.43 & 1.17 & 2.50 & 1.24 \\
\hline $\begin{array}{l}\text { 9,12-Hexadecadienoic acid, } \\
\text { methyl ester }\end{array}$ & & nd & nd & nd & 1.15 \\
\hline 9,12-Octadecadienoic acid (Z,Z)- & & 3.53 & nd & 3.97 & nd \\
\hline $\begin{array}{l}\text { Hexadecanoic acid, 2-hydroxy-1- } \\
\text { (hydroxymethyl)ethyl ester }\end{array}$ & & nd & nd & 2.99 & nd \\
\hline $\begin{array}{l}\text { 9,12-Octadecadienoic acid (Z,Z)-, } \\
\text { 2,3-dihydroxypropyl ester }\end{array}$ & & 1.42 & nd & 2.96 & nd \\
\hline Ergosterol & & 1.68 & nd & nd & 0.56 \\
\hline $\begin{array}{l}\text { Pyrrolo[1,2-a] pyrazine-1,4-dione, } \\
\text { hexahydro-3-(phenylmethyl)- }\end{array}$ & & nd & 1.39 & 0.51 & 0.58 \\
\hline
\end{tabular}

nd: not detected. Identified substances with a relative peak area less than $0.5 \%$ were not listed in the table. FD—freeze drying; HAD—hot air drying; MWD—microwave drying; SD—sun drying.

Extracts from dry fruit bodies of Pleurotus ostreatus in simulated gastrointestinal digestion containing more than 50 compounds in the range of $0.22 \%$ to $48.62 \%$, identified from the database of the NIST0,5a library. These include alcohols, aldehydes, acids and esters, heterocyclic compounds, fatty acids, amino acids, peptides, aromatic and other compounds. MWD samples had the largest number of identified substances. The relative percentage of many compounds was higher in MWD and FD extracts than in HAD and SD.

\subsubsection{MALDI-TOF Mass Spectrometry}

The study of the peptide profile of the dry oyster mushroom after the imitation of digestion in vitro showed that the mass spectra of FD and HAD extracts included signals of varying intensity in the range of 160-2200 Da (Figure 5). 


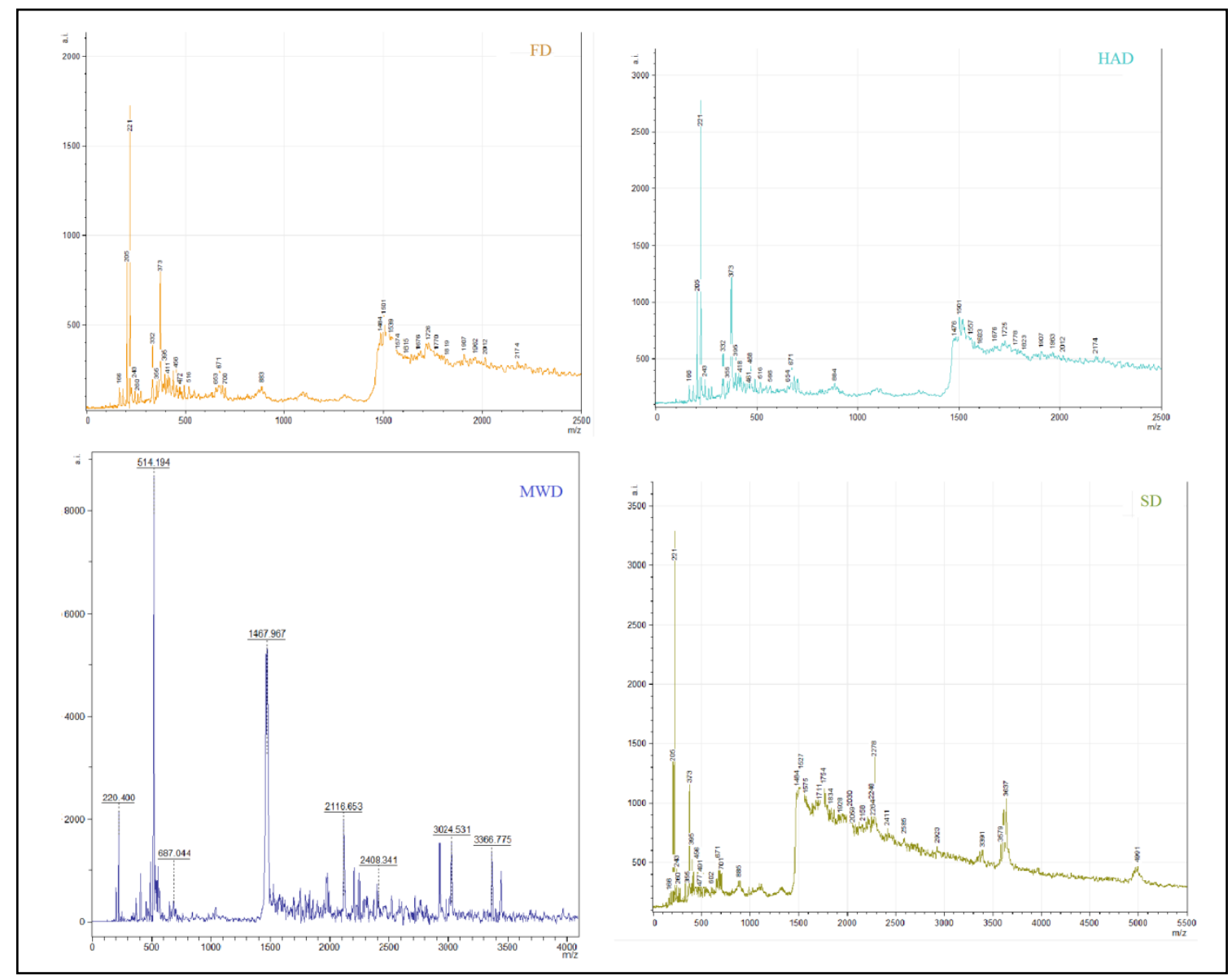

Figure 5. Data of the MALDI-TOF mass spectrometry of dry fruiting bodies Pleurotus ostreatus after in vitro digestion. FD—freeze drying; HAD—hot air drying; MWD—microwave drying; SD—sun drying.

The range of MWD samples mass spectra was 180-3400 Da, SD samples 160-5000 Da. At the same time, 17 signals from $\mathrm{m} / \mathrm{z}$ from 160 to $885 \mathrm{Da}$ and 13 signals in the range of 1450-2200 Da were detected in FD and HAD samples. For MWD samples 12 signals were recorded in the range of 180-760 Da, 11 signals in the range of 1400-3400 Da. The scales of SD samples included 15 signals from $\mathrm{m} / \mathrm{z}$ to $900 \mathrm{Da}$ and about 20 signals in the range of 1400-5000 Da.

The peptide profile of dry fruit bodies of the oyster mushroom after digestion in the aspect of antioxidant and ACE inhibitory activities, obtained using the BIOPEP database, is presented in Table 4.

\subsection{Influence of Drying Processes on the Antioxidative Activity of Pleurotus Ostreatus In Vitro for the Simulation of Gastrointestinal Digestion}

There is not a single universal method capable of providing an accurate and comprehensive picture of the antioxidant profile, as several mechanisms underlying the antioxidant activity of mushrooms are identified, including the adjustment of the indirect chain reaction with free radicals, hydrogen donation, chelation of catalytic ions, removal of peroxides [36]. A single analysis is not sufficient to measure the antioxidant capacity, so a total of five methods were used in this study: ABTS radical scavenging activity, reducing performance activity, iron reducibility (the FRAP assay), total antioxidant capacity according to the electrochemical method, and lipid peroxidation inhibition test (Table 5). 
Table 4. Characterization of the peptide profile of the dry fruit bodies of Pleurotus ostreatus after in vitro digestion (in accordance with the BIOPEP database).

\begin{tabular}{|c|c|c|c|c|c|c|c|}
\hline $\begin{array}{l}\text { Chemical } \\
\text { Mass, Da }\end{array}$ & ID & Sequence & Activity & FD & HAD & MWD & SD \\
\hline \multirow[t]{5}{*}{243} & 3342 & GPA & ACE inhibitor & + & + & - & + \\
\hline & 7810 & $\mathrm{KP}$ & ACE inhibitor & + & + & - & + \\
\hline & 7837 & $\mathrm{PQ}$ & ACE inhibitor & + & + & - & + \\
\hline & 9041 & AGP & ACE inhibitor & + & + & - & + \\
\hline & 8218 & $\mathrm{KP}$ & antioxidative & + & + & - & + \\
\hline 355 & 8000 & LHS & antioxidative & + & + & - & + \\
\hline 373 & 7654 & NKL & ACE inhibitor & + & + & + & + \\
\hline 395 & 8220 & TFE & antioxidative & + & + & - & + \\
\hline \multirow[t]{10}{*}{405} & 3301 & $\mathrm{HLH}$ & antioxidative & - & - & + & - \\
\hline & 3302 & $\mathrm{LHH}$ & antioxidative & - & - & + & - \\
\hline & 7909 & $\mathrm{IHH}$ & antioxidative & & - & + & - \\
\hline & 7919 & $\mathrm{NHH}$ & antioxidative & - & - & + & - \\
\hline & 7984 & $\mathrm{HIH}$ & antioxidative & - & - & + & - \\
\hline & 8017 & LWS & antioxidative & - & - & + & - \\
\hline & 8225 & SWN & antioxidative & - & - & + & - \\
\hline & 9179 & QYP & antioxidative & - & - & + & - \\
\hline & 9190 & MAW & ACE inhibitor & - & - & + & - \\
\hline & 9350 & TTW & ACE inhibitor & - & - & + & - \\
\hline 456 & 7652 & KFY & ACE inhibitor & + & + & - & + \\
\hline \multirow[t]{10}{*}{472} & 3364 & HGLF & ACE inhibitor & + & - & - & + \\
\hline & 7551 & YQY & ACE inhibitor & + & - & - & + \\
\hline & 7651 & YKY & ACE inhibitor & + & - & - & + \\
\hline & 7653 & KYY & ACE inhibitor & + & - & & + \\
\hline & 7931 & KYY & antioxidative & + & - & - & + \\
\hline & 7934 & YKY & antioxidative & + & - & - & + \\
\hline & 7937 & YYK & antioxidative & + & - & - & + \\
\hline & 7948 & YYQ & antioxidative & + & - & - & + \\
\hline & 7966 & QYY & antioxidative & + & - & - & + \\
\hline & 7969 & YQY & antioxidative & + & - & - & + \\
\hline \multirow[t]{3}{*}{477} & 3364 & HGLF & ACE inhibitor & + & - & - & + \\
\hline & 7551 & YQY & ACE inhibitor & + & - & - & + \\
\hline & 7651 & YKY & ACE inhibitor & + & - & - & + \\
\hline \multirow[t]{6}{*}{491} & 7904 & SALAM & antioxidative & - & + & - & + \\
\hline & 7943 & YYF & antioxidative & - & + & - & + \\
\hline & 7961 & FYY & antioxidative & - & + & - & + \\
\hline & 7963 & YFY & antioxidative & - & + & - & + \\
\hline & 8431 & MGSPT & antioxidative & - & + & - & + \\
\hline & 9070 & MRW & ACE inhibitor & - & + & - & + \\
\hline 516 & 8078 & RWR & antioxidative & + & + & + & - \\
\hline 552 & 9242 & PLPLL & ACE inhibitor & - & - & + & - \\
\hline 566 & 7485 & TKVIP & ACE inhibitor & & + & - & - \\
\hline \multirow[t]{2}{*}{602} & 8278 & VPYPQ & antioxidative & - & - & - & + \\
\hline & 8963 & VPVST & antioxidative & - & - & - & + \\
\hline \multirow[t]{4}{*}{654} & 3566 & EPKAIP & ACE inhibitor & + & + & - & - \\
\hline & 3970 & WLAHK & ACE inhibitor & + & + & - & - \\
\hline & 9217 & TFPHGP & ACE inhibitor & + & + & - & - \\
\hline & 8430 & HVAGTVA & antioxidative & + & + & - & - \\
\hline
\end{tabular}


Table 4. Cont.

\begin{tabular}{|c|c|c|c|c|c|c|c|}
\hline $\begin{array}{l}\text { Chemical } \\
\text { Mass, Da }\end{array}$ & ID & Sequence & Activity & FD & HAD & MWD & SD \\
\hline \multirow[t]{4}{*}{671} & 3367 & GKKVLQ & ACE inhibitor & + & + & - & + \\
\hline & 9099 & MTEEY & ACE inhibitor & + & + & - & + \\
\hline & 9109 & LIWKL & ACE inhibitor & + & + & - & + \\
\hline & 9100 & MTEEY & antioxidative & + & + & - & + \\
\hline \multirow[t]{5}{*}{687} & 2651 & VLPYPV & ACE inhibitor & - & - & - & + \\
\hline & 2667 & LHLPLP & ACE inhibitor & - & - & - & + \\
\hline & 3575 & QPQAFP & ACE inhibitor & - & - & - & + \\
\hline & 7568 & KVREGT & ACE inhibitor & - & - & - & + \\
\hline & 8730 & RWAEK & antioxidative & - & - & - & + \\
\hline \multirow[t]{3}{*}{699} & 3420 & GVYPHK & ACE inhibitor & - & - & + & - \\
\hline & 8305 & QLGNLGV & antioxidative & - & - & + & - \\
\hline & 8950 & WCTSVS & antioxidative & - & - & + & - \\
\hline \multirow[t]{4}{*}{701} & 9443 & AGDDAPR & antioxidative & + & - & - & + \\
\hline & 9444 & GKDAVIV & antioxidative & + & - & - & + \\
\hline & 8306 & RDVPSLM & antioxidative & + & - & - & + \\
\hline & 9449 & IDDVLK & antioxidative & + & - & - & + \\
\hline \multirow[t]{4}{*}{884} & 9224 & MPVHTDAD & ACE inhibitor & + & + & - & + \\
\hline & 9445 & AIGVGAIEP & antioxidative & + & + & - & + \\
\hline & 9531 & SNLCRPCD & antioxidative & + & + & - & + \\
\hline & 8448 & WHNVSGSP & antioxidative & + & + & - & + \\
\hline 1615 & 8100 & LKQELEDLLEKQE & antioxidative & + & - & - & - \\
\hline 1726 & 3809 & LQSGDALRVPSGTTYY & antioxidative & + & + & - & + \\
\hline \multirow[t]{2}{*}{1754} & 9240 & LVYPFPGPIPNSLPQN & ACE inhibitor & - & - & - & + \\
\hline & 9370 & VKRRGQDCIHGFCSD & antioxidative & - & - & - & + \\
\hline 1778 & 8464 & LVMFLDNQHRVIRH & antioxidative & - & + & - & - \\
\hline 2012 & 9201 & DPAQPNYPWTAVLVFRH & antioxidative & + & + & - & - \\
\hline
\end{tabular}

FD—freeze drying; HAD—hot air drying; MWD—microwave drying; SD—sun drying.

Table 5. ABTS radical scavenging activity, reducing power activity and ferric reducing ability (the FRAP assay) of dry fruit bodies Pleurotus ostreatus after in vitro digestion $(\mathrm{M} \pm \mathrm{m})$.

\begin{tabular}{ccccc}
\hline Drying Method & $\begin{array}{c}\text { ABTS Radical } \\
\text { Scavenging } \\
\text { Activity } \\
\mu \text { molTrolox/g }\end{array}$ & $\begin{array}{c}\text { Reducing Power } \\
\text { Activity mg } \\
\text { Equivalent to } \\
\text { Ascorbic Acid/g }\end{array}$ & $\begin{array}{c}\text { Ferric Reducing } \\
\text { Ability mg } \\
\text { Equivalent to } \\
\text { Ascorbic Acid/g }\end{array}$ & $\begin{array}{c}\text { Total Antioxidant Capacity } \\
\text { by the Electrochemical } \\
\text { Method mg Equivalent to } \\
\text { Gallic Acid/L }\end{array}$ \\
\hline FD & $24.0 \pm 1.04^{\mathrm{a}}$ & $8.76 \pm 0.36^{\mathrm{a}}$ & $3.26 \pm 0.14^{\mathrm{a}}$ & $9.04 \pm 0.26^{\mathrm{a}}$ \\
HAD & $24.8 \pm 1.23^{\mathrm{a}}$ & $12.4 \pm 0.54^{\mathrm{b}}$ & $4.15 \pm 0.17^{\mathrm{b}}$ & $10.99 \pm 0.21^{\mathrm{b}}$ \\
MWD & $28.6 \pm 1.25^{\mathrm{b}}$ & $14.2 \pm 0.62^{\mathrm{c}}$ & $5.03 \pm 0.23^{\mathrm{c}}$ & $7.09 \pm 0.38^{\mathrm{c}}$ \\
SD & $25.4 \pm 1.10^{\mathrm{a}}$ & $9.8 \pm 0.43^{\mathrm{d}}$ & $3.38 \pm 0.14^{\mathrm{a}}$ & $7.39 \pm 0.28^{\mathrm{c}}$ \\
\hline
\end{tabular}

Different superscript letters indicate statistically significant differences between the means $(p<0.05)$ for each parameter. FD—freeze drying; HAD—hot air drying; MWD—-microwave drying; SD—sun drying.

ABTS analysis is often used to determine the total antioxidant capacity of individual compounds and complex mixtures of different plants [55]. According to the available tabular data, the average values of radical absorption activity obtained with the ABTS method for oyster mushroom extracts of dried FD, HAD, and SD did not differ statistically. The maximum radical-binding effect was observed in oyster mushroom extract dehydrated MWD and significantly exceeded the other samples in this indicator. The differences revealed despite the data from Duan and $\mathrm{Xu}$ [17], which indicate a lower safety of the antioxidant properties of mushroom dried MWD, can be explained by the destruction of cell walls by microwaves, which allow the availability of antioxidants for extraction. In addition, the relatively high antiradical activity of MWD samples may be associated with a high content of succinic acid (butanedioic acid, monomethyl ester), almost 14 times higher than that of FD, HAD and SD samples (see results of GC-MS above). This substance not only has an antioxidant effect alone, 
but also according to Kolupaev et al. [56] increases the activity of antioxidant enzymes: catalases and peroxidases.

The leading position of MWD extracts in the radical absorption activity of ABTS may also be due to the maximum number of peptides in their composition, consistent with the results of several researchers [35], which shows the relationship between antioxidant activity and mushrooms peptides. However, contrary to our assumption, the results of the MALDI-TOF mass spectrometric analysis of the peptide profile show a small representation of antioxidant peptides in MWD samples, which indicates other mechanisms of high activity of radical absorption of mushrooms obtained by microwave drying.

The reduction in performance activity of extracts in ascending order was distributed as follows: $\mathrm{FD}<\mathrm{SD}<\mathrm{HAD}<\mathrm{MWD}$. The results obtained of the largest manifestation of regenerative capacity of MWD samples are consistent with the data of Ji et al. [13] and their assumption that microwave-dried mushrooms have the ability to release electrons to reactive free radicals, transform them into more stable, non-reactive particles and terminate the chain reaction of free radicals.

The comparison of the ferric reduction capacity shows that the methods for drying FD and SD provide very accurate results $(3.26 \pm 0.08 \mathrm{mg} / \mathrm{g} ; 3.38 \pm 0.08 \mathrm{mg} / \mathrm{g})$ with respect to the mushroom species studied. Of the four samples, MWD $(5.03 \pm 0.13 \mathrm{mg} / \mathrm{g})$ and HAD $(4.15 \pm 0.10 \mathrm{mg} / \mathrm{g})$ oyster mushroom extracts were the most effective in terms of iron restoration ability. The results obtained confirm the data of Ji et al. [13] and may be based on Dalmau et al. [18] and Heleno et al. [57] are caused by the enzymatic degradation of antioxidant compounds in the application of long-term dehydrogenation methods at low temperatures such as lyophilization and solar drying.

In addition, higher rates of iron reducing capacity of oyster mushroom extracts dried by MWD and HAD processes and characterized by heating may be associated with the release of phytochemical compounds caused by the thermal destruction of cell components and the formation of new substances with increased antioxidant potential, such as Maillard reaction products [58]. This is supported by literature reports on increased antioxidant activity after heat treatment of some raw materials such as tomatoes [51], mushrooms [59] and ginseng [60]. For example, according to Čechovská et al. [61], an increase in the antioxidant activity of plums after high temperature drying is achieved by the resulting substance $4 \mathrm{H}$-pyran-4-on,2,3-dihydro-3,5-dihydroxy-6-methyl, which is the main product of the Maillard reaction, and in the extracts of the dry oyster mushrooms examined, only MWD samples were recorded (see above results of GC-MS).

The role of phenols in providing superior iron reduction capability of MWD and HAD samples, which are characterized by their highest content, is also possible. According to Ferreira et al. [47] and Muszyńska et al. [62] phenolic compounds can chelate elements (e.g., $\mathrm{Fe}, \mathrm{Cu}$ ) which can produce reactive oxygen species.

HAD extracts were the leading electrochemical method to assess the total antioxidant activity of dry oyster extracts. The remainder of the samples was distributed in the following order of acceptance FD $>$ SD > MWD. Paradoxically, MWD extracts showing the highest antioxidant activity registered by spectrophotometric methods (Reducing Power Activity, ABTS, FRAP assay) were characterized by the lowest values of total antioxidant activity determined by the electrochemical method. This confirms that the already available data [63] may be associated with a low concentration of low molecular weight substances in the MWD extract, in particular, amino acids, whose antioxidant activity is the effect on electrochemical oxygen recovery effectively demonstrated by the above method. Thus, according to the above data, the largest amount of amino acids was found in HAD extracts $(4.16 \pm 0.18 \mathrm{~g} / \mathrm{L})$, the lowest in MWD samples ( $3.51 \pm 0.15 \mathrm{~g} / \mathrm{L}$ ). According to the above data from GC-MS, only alanine and phenylalanine amino acids were found in HAD extracts and the concentrations of ornithine, leucine and uric amino acids were many times higher than in FD and SD samples. These amino acids were not identified at all in MWD extracts.

No less interesting were the results of estimating the inhibition of lipid oxidation reactions. Samples of extracts from oyster mushroom dried SD were significantly differentiated by the degree 
of inhibition of lipid oxidation. The samples subjected to other drying methods had no statistically significant differences in the value of this activity (Figure 6).

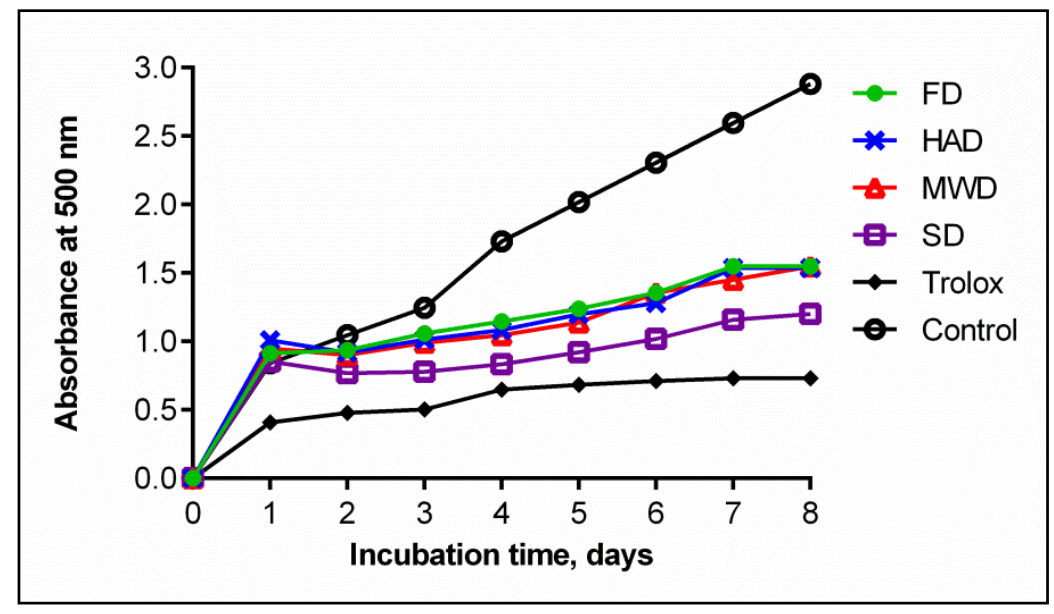

Figure 6. Lipid peroxidation inhibition of dry fruiting bodies Pleurotus ostreatus after in vitro digestion. Lower absorbance at $500 \mathrm{~nm}$ represents higher lipid peroxidation inhibition. FD—freeze drying; HAD —hot air drying; MWD—microwave drying; SD—sun drying.

Phenolic substances in mushrooms are known to play an important role in inhibiting lipid oxidation [64]. In our study, there was no correlation between phenol concentration and activity to block lipid oxidation processes.

This may indicate the role of other secondary metabolites in inhibiting lipid oxidation reactions, the content of which, according to Kim et al. [65], increases the process of drying mushrooms in the sun by activating specific enzymes that catalyze the biosynthesis of secondary metabolites by ultraviolet radiation. According to the above results of GC-MS extracts such substances may be: pyrrolo[1,2-a]pyrazine-1,4-dione,hexahydro-3-(2-methylpropyl)-; DL-valine; 2-dimethylsilyloxytetradecane; d-mannitol,1,4-anhydro-; DL-proline,5-oxo-; 4-cyanobenzoic acid, 2-phenyl ethyl ester. These compounds were much less numerous in FD, HAD and MWD samples than in SD-dried mushrooms or were not present at all. This is partially confirmed by Manimaran \& Kannabiran [66], which indicates the ability of some of these substances to participate in antioxidant reactions.

\subsection{ACE Inhibitory Activity}

ACE inhibitory activity of mushrooms, the genus Pleurotus, is confirmed by a number of studies. Available data on ACE inhibitory activity focus on the action of proteins and bioactive peptides $[67,68]$.

ACE inhibitory activity of oyster mushroom dried in various ways was evaluated after the simulation of gastrointestinal digestion. The results were expressed in IC50 units showing the concentration of the substance required to inhibit $50 \%$ of ACE activity (Figure 7).

The obtained values were correlated with the results of other researchers [36] and once again demonstrated the potential of oysters for ACE inhibition. At the same time, it was found that the activity of ACE-inhibiting mushrooms after the simulation of gastrointestinal digestion differed significantly depending on the drying method used. FD mushrooms showed maximum activity with respect to ACE IC50 inhibition $(0.51 \pm 0.03 \mathrm{mg} / \mathrm{mL})$. The value of ACE IC50 oyster mushroom inhibition activity dried $\mathrm{HAD}$ and SD was $1.07 \pm 0.06 \mathrm{mg} / \mathrm{mL}$ and $0.61 \pm 0.05 \mathrm{mg} / \mathrm{mL}$, respectively. The lowest ACE inhibitory activity was shown by dried MWD mushrooms $(3.04 \pm 0.19 \mathrm{mg} / \mathrm{mL})$. Probably, heating and microwave radiation lead to the destruction of active proteins and peptides of mushrooms with the property of ACE inhibition. This is logically confirmed by the lowest ACE representation of inhibitory peptides in MWD samples described above and echoes the results of the proteomic analysis performed by Lau [69], 
according to which lyophilic drying provides high ACE inhibitory activity of mushroom sublimates due to the preservation of a wide range of proteins, including low-molecular weight proteins, which are potential ACE inhibitors.

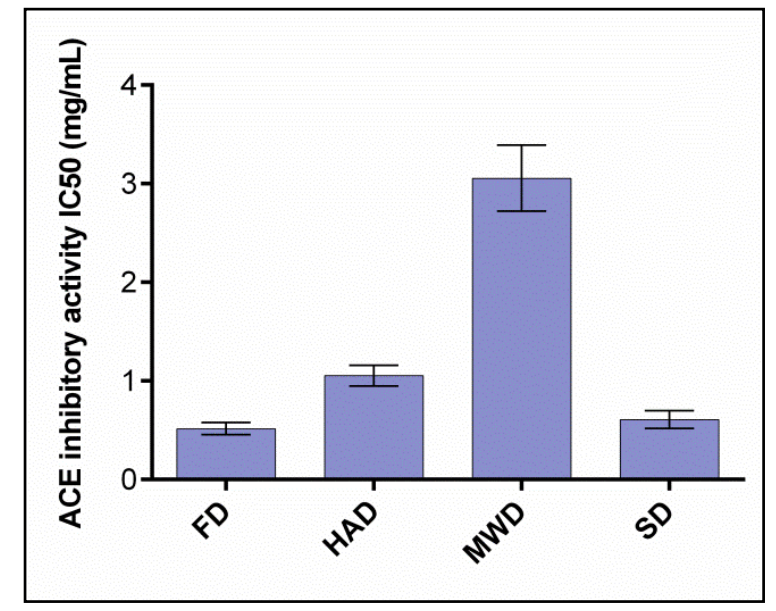

Figure 7. ACE inhibitory activity IC50 (mg/mL) of dry fruit bodies Pleurotus ostreatus after in vitro digestion. FD—freeze drying; HAD—hot air drying; MWD—microwave drying; SD—sun drying.

In addition, the minimal ACE inhibition activity of dried MWD mushrooms can also be explained by the high-temperature inactivation of the proteinase inhibitors contained in the mushrooms, which block the activity of gastrointestinal enzymes and, as a result, increased the digestive damage of ACE-active protein and peptide inhibition.

\section{Conclusions}

In this study it was found that various methods for drying fruiting bodies of Pleurotus ostreatus have different effects on the structural properties, rehydration capacity and thus on the chemical composition and antioxidant profile of the dry product in experimental gastrointestinal digestion. Pleurotus ostreatus studied showed good antioxidant capacity and potential antihypertensive effect as demonstrated by their inhibitory effect towards ACE.

Using different methods of estimating antioxidant activity based on different chemical reactions, the peculiarities of the antioxidant properties of Pleurotus ostreatus fruiting bodies dried in various ways were identified and the most effective methods of drying to obtain oyster mushrooms with the greatest antioxidant effect were determined for different application points of antiradical function. It was found that under the conditions of the gastrointestinal digestive model in vitro the dry oyster mushroom as a food product or its component has the highest radical absorption activity after microwave drying. The reduction of performance activity and iron-reducing ability of oyster mushroom is maximally preserved in microwave drying and hot-air drying. Antioxidant properties based on the mechanisms of electrochemical oxygen recovery manifest most in mushrooms dewatered with hot air. The properties of the antioxidant with emphasis on a high activity of inhibiting lipid oxidation of the oyster mushroom are largely preserved after drying in the sun. After the simulation of gastrointestinal digestion, mushrooms dried lyophilically and in the sun showed relatively high ACE inhibitory activity.

At the same time, we cannot ignore the fact that the drying methods used in this study differ significantly in terms of process complexity, energy consumption and, consequently, cost. The choice between drying methods will therefore depend on the final product. For example, if the intention is to obtain a dry oyster mushroom product with high ABTS radical scavenging activity, reducing power activity and ferric reducing ability, then microwave drying may be the relatively best choice. Drying in a microwave oven compared to hot air drying significantly reduces the drying time and is more energy efficient. If, however, there is a need for a product with a pronounced electrochemical oxygen recovery 
capability and a relatively high ACE-inhibiting activity, hot air drying, despite its higher cost, is the best option.

In the case of a dry oyster mushroom product with an emphasis only on the maximum ACE-inhibiting activity, of the two methods of drying: lyophilic and solar drying, it would be more rational to choose the latter. The method of drying in the sun compared to lyophilic drying is simple, has no special requirements for expensive equipment and is characterized by significantly lower costs.

The complex and costly method of lyophilic drying of Pleurotus ostreatus is not excluded and can be considered as an alternative in the case of obtaining a substance with high ACE-inhibiting activity in the production of complex biopreparation, in order to preserve thermolability and to stabilize the action of oxygen and UV irradiation substances that provide other properties of oyster mushrooms, not considered in this study.

Thus, the experimental substantiation of separate drying methods provides an antioxidant or ACE inhibitory effect when obtaining a dry product of oyster mushrooms as a potential functional food product or an ingredient with the maximum expression of the whole complex or separate properties.

Author Contributions: Conceptualization, S.P.; L.T.; and W.-D.G.; formal analysis, S.P. and S.A.; investigation, I.R.; S.A.; V.K. and M.S.; writing—original draft preparation, S.P.; L.T.; W.-D.G. and V.K.; writing—review and editing, S.P.; W.-D.G.; L.T.; M.S. and I.R.; supervision, L.T.; project administration, S.P. and L.T.; funding acquisition, I.R. and W.-D.G. All authors have read and agreed to the published version of the manuscript.

Funding: This research received no external funding.

Conflicts of Interest: The authors declare no conflict of interest.

\section{References}

1. Vidović, S.S.; Mujić, I.O.; Zeković, Z.P.; Lepojević, Ž.D.; Tumbas, V.T.; Mujić, A.I. Antioxidant Properties of Selected Boletus Mushrooms. Food Biophys. 2009, 5, 49-58. [CrossRef]

2. Willett, W.S. Eat, Drink, and Be Healthy: The Harvard Medical School Guide to Healthy Eating; Simon and Schuster: New York, NY, USA, 2001.

3. Munzel, T.; Keaney, J.F. Are ACE Inhibitors a “Magic Bullet" Against Oxidative Stress? Circulation 2001, 104, 1571-1574. [CrossRef] [PubMed]

4. Maslov, L.N.; Naryzhnaya, N.V.; Boshchenko, A.A.; Popov, S.V.; Ivanov, V.V.; Oeltgen, P.R. Is oxidative stress of adipocytes a cause or a consequence of the metabolic syndrome? J. Clin. Transl. Endocrinol. 2019, 15, 1-5. [CrossRef] [PubMed]

5. Yunusova, N.V.; Kondakova, I.V.; Kolomiets, L.A.; Afanas'ev, S.G.; Kishkina, A.Y.; Spirina, L.V. The role of metabolic syndrome variant in the malignant tumor's progression. Diabetes Metab. Syndr. Clin. Res. Rev. 2018, 12, 807-812. [CrossRef]

6. Skurikhin, E.G.; Pershina, O.V.; Pakhomova, A.V.; Pan, E.S.; Krupin, V.A.; Ermakova, N.N.; Vaizova, O.E.; Pozdeeva, A.S.; Zhukova, M.A.; Skurikhina, V.E.; et al. Endothelial Progenitor Cells as Pathogenetic and Diagnostic Factors, and Potential Targets for GLP-1 in Combination with Metabolic Syndrome and Chronic Obstructive Pulmonary Disease. Int. J. Mol. Sci. 2019, 20, 1105. [CrossRef]

7. Lu, X.; Brennan, M.A.; Serventi, L.; Liu, J.; Guan, W.; Brennan, C.S. Addition of mushroom powder to pasta enhances the antioxidant content and modulates the predictive glycaemic response of pasta. Food Chem. 2018, 264, 199-209. [CrossRef]

8. Proserpio, C.; Pagliarini, E.; Laureati, M.; Frigerio, B.; Lavelli, V. Acceptance of a New Food Enriched in $\beta$-Glucans among Adolescents: Effects of Food Technology Neophobia and Healthy Food Habits. Foods 2019, 8, 433. [CrossRef]

9. Sałata, A.; Lemieszek, M.; Parzymies, M. The nutritional and health properties of an oyster mushroom (Pleurotus ostreatus (Jacq. Fr) P. Kumm.). Acta Sci. Pol. Hortorum Cultus. 2018, 17, 185-197. [CrossRef]

10. Yan, J.; Zhu, L.; Qu, Y.; Qu, X.; Mu, M.; Zhang, M.; Sun, L. Analyses of active antioxidant polysaccharides from four edible mushrooms. Int. J. Biol. Macromol. 2019, 123, 945-956. [CrossRef] 
11. Koutrotsios, G.; Kalogeropoulos, N.; Kaliora, A.C.; Zervakis, G.I. Toward an Increased Functionality in Oyster (Pleurotus) Mushrooms Produced on Grape Marc or Olive Mill Wastes Serving as Sources of Bioactive Compounds. J. Agric. Food Chem. 2018, 66, 5971-5983. [CrossRef]

12. Liu, D.; Chen, Y.-Q.; Xiao, X.-W.; Zhong, R.-T.; Yang, C.-F.; Liu, B.; Zhao, C. Nutrient Properties and Nuclear Magnetic Resonance-Based Metabonomic Analysis of Macrofungi. Foods 2019, 8, 397. [CrossRef] [PubMed]

13. Ji, H.; Du, A.; Zhang, L.; Li, S.; Yang, M.; Li, B. Effects of Drying Methods on Antioxidant Properties and Phenolic Content in White Button Mushroom. Int. J. Food Eng. 2012, 8, 1-14. [CrossRef]

14. Piskov, S.I.; Timchenko, L.D.; Rzhepakovsky, I.V.; Avanesyan, S.S.; Bondareva, N.I.; Sizonenko, M.N.; Areshidze, D.A. Effect of pre-treatment conditions on the antiatherogenic potential of freeze-dried oyster mushrooms. Foods Raw Mater. 2019, 7, 375-386. [CrossRef]

15. Maray, A.R.M.; Mostafa, M.K.; El-Fakhrany, A.E.-D.M.A. Effect of pretreatments and drying methods on physico-chemical, sensory characteristics and nutritional value of oyster mushroom. J. Food Process. Preserv. 2017, 42, e13352. [CrossRef]

16. Tian, Y.; Zhao, Y.; Huang, J.; Zeng, H.; Zheng, B. Effects of different drying methods on the product quality and volatile compounds of whole shiitake mushrooms. Food Chem. 2016, 197, 714-722. [CrossRef]

17. Duan, J.-L.; Xu, J.-G. Effects of Drying Methods on Physico-Chemical Properties and Antioxidant Activity of Shiitake Mushrooms (Lentinus edodes). Agric. Food Sci. Res. 2015, 2, 51-55.

18. Dalmau, M.E.; Bornhorst, G.M.; Eim, V.; Rosselló, C.; Simal, S. Effects of freezing, freeze drying and convective drying on in vitro gastric digestion of apples. Food Chem. 2017, 215, 7-16. [CrossRef]

19. Ucar, T.M.; Karadag, A. The effects of vacuum and freeze-drying on the physicochemical properties and in vitro digestibility of phenolics in oyster mushroom (Pleurotus ostreatus). J. Food Meas. Charact. 2019, 13, 2298-2309. [CrossRef]

20. Parniakov, O.; Bals, O.; Lebovka, N.; Vorobiev, E. Pulsed electric field assisted vacuum freeze-drying of apple tissue. Innov. Food Sci. Emerg. Technol. 2016, 35, 52-57. [CrossRef]

21. Prosapio, V.; Norton, I. Influence of osmotic dehydration pre-treatment on oven drying and freeze drying performance. LWT 2017, 80, 401-408. [CrossRef]

22. Al-Amin, M.; Hossain, M.S.; Iqbal, A. Effect of pre-treatments and drying methods on dehydration and rehydration characteristics of carrot. Univers. J. Food Nutr. Sci. 2015, 3, 23-28. [CrossRef]

23. Ando, Y.; Maeda, Y.; Mizutani, K.; Wakatsuki, N.; Hagiwara, S.; Nabetani, H. Impact of blanching and freeze-thaw pretreatment on drying rate of carrot roots in relation to changes in cell membrane function and cell wall structure. LWT-Food Sci. Technol. 2016, 71, 40-46. [CrossRef]

24. Hernando, I.; Sanjuán, N.; Pérez-Munuera, I.; Mulet, A. Rehydration of Freeze-Dried and Convective Dried Boletus edulis Mushrooms: Effect on Some Quality Parameters. J. Food Sci. 2008, 73, E356-E362. [CrossRef]

25. Cafarelli, B.; Spada, A.; Laverse, J.; Lampignano, V.; Del Nobile, M.A. X-ray microtomography and statistical analysis: Tools to quantitatively classify bread microstructure. J. Food Eng. 2014, 124, 64-71. [CrossRef]

26. McDougall, G.J.; Fyffe, S.; Dobson, P.; Stewart, D. Anthocyanins from red wine-Their stability under simulated gastrointestinal digestion. Phytochemistry 2005, 66, 2540-2548. [CrossRef]

27. Lahl, W.J.; Braun, S.D. Enzymatic production of protein hydrolysates for food use. Food Technol. 1994, 48, 68-71.

28. Gornall, A.G.; Baradawill, J.; David, M. Determination of serum protein by means of the biuret reaction. J. Biol. Chem. 1949, 77, 751-766.

29. Swain, T.; Hills, W.E. The phenolic constituents of Prunus domestica. J. Sci. Food Agric. 1959, 10, 63-68. [CrossRef]

30. Chang, C.-C.; Yan, M.-H.; Wen, H.-M.; Chern, J.-C. Estimation of Total Flavonoid Content in Propolis by Two Complementary Colorimetric Methods. J. Food Drug Anal. 2002, 10, 178-182.

31. Minkiewicz, P.; Iwaniak, A.; Darewicz, M. BIOPEP-UWM Database of Bioactive Peptides: Current Opportunities. Int. J. Mol. Sci. 2019, 20, 5978. [CrossRef]

32. Klompong, V.; Benjakul, S.; Kantachote, D.; Shahidi, F. Antioxidative activity and functional properties of protein hydrolysate of yellow stripe trevally (Selaroides leptolepis) as influenced by the degree of hydrolysis and enzyme type. Food Chem. 2007, 102, 1317-1327. [CrossRef]

33. Piljac-Žegarac, J.; Valek, L.; Stipčević, T.; Martinez, S. Electrochemical determination of antioxidant capacity. Food Chem. 2010, 121, 820-825. [CrossRef] 
34. Hoyos-Arbeláez, J.; Vázquez, M.; Contreras-Calderón, J. Electrochemical methods as a tool for determining the antioxidant capacity of food and beverages: A review. Food Chem. 2017, 221, 1371-1381. [CrossRef]

35. Kimatu, B.M.; Zhao, L.; Biao, Y.; Ma, G.; Yang, W.; Pei, F.; Hu, Q. Antioxidant potential of edible mushroom (Agaricus bisporus) protein hydrolysates and their ultrafiltration fractions. Food Chem. 2017, 230, 58-67. [CrossRef]

36. Abdullah, N.; Ismail, S.M.; Aminudin, N.; Shuib, A.S.; Lau, B.F. Evaluation of Selected Culinary-Medicinal Mushrooms for Antioxidant and ACE Inhibitory Activities. Evidence-Based Complementary Altern. Med. 2012, 2012, 1-12. [CrossRef]

37. Rudy, S.; Dziki, D.; Krzykowski, A.; Gawlik-Dziki, U.; Polak, R.; Różyło, R.; Kulig, R. Influence of pre-treatments and freeze-drying temperature on the process kinetics and selected physico-chemical properties of cranberries (Vaccinium macrocarpon Ait.). LWT Food Sci. Technol. 2015, 63, 497-503. [CrossRef]

38. Izli, N.; Isik, E. Effect of different drying methods on drying characteristics, colour and microstructure properties of mushroom. J. Food Nutr. Res. 2014, 53, 105-116.

39. Piskov, S.I.; Timchenko, L.D.; Rzhepakovsky, I.V.; Avanesyan, S.S.; Sizonenko, M.N.; Areshidze, D.A.; Kovalev, D.A. The influence of the drying method for food properties and hypolidemic potential of oyster mushrooms (Pleurotus ostreatus). Vopr. Pitan. Probl. Nutr. 2018, 87, 65-76. [CrossRef]

40. Niamnuy, C.; Devahastin, S.; Soponronnarit, S. Some recent advances in microstructural modification and monitoring of foods during drying: A review. J. Food Eng. 2014, 123, 148-156. [CrossRef]

41. Laverse, J.; Frisullo, P.; Conte, A.; Del Nobile, M.A. X-Ray Microtomography for Food Quality Analysis. In Food Industrial Processes-Methods and Equipment; Benjamin, V., Ed.; InTech: Vienna, Austria, 2012; pp. 339-362. [CrossRef]

42. Apati, G.P.; Furlan, S.A.; Laurindo, J.B. Drying and rehydration of oyster mushroom. Braz. Arch. Biol. Technol. 2010, 53, 945-952. [CrossRef]

43. Singh, N.J.; Pandey, R.K. Rehydration characteristics and structural change of sweet potato cubes after dehydration. Am. J. Food Technol. 2011, 6, 709-716. [CrossRef]

44. Seremet (Ceclu), L.; Botez, E.; Nistor, O.-V.; Andronoiu, D.G.; Mocanu, G.-D. Effect of different drying methods on moisture ratio and rehydration of pumpkin slices. Food Chem. 2016, 195, 104-109. [CrossRef] [PubMed]

45. Jin, B.; Zhou, X.; Li, B.; Lai, W.; Li, X. Influence of In vitro Digestion on Antioxidative Activity of Coconut Meat Protein Hydrolysates. Trop. J. Pharm. Res. 2015, 14, 441. [CrossRef]

46. Sun, J.; He, H.; Xie, B.J. Novel Antioxidant Peptides from Fermented Mushroom Ganoderma Lucidum. J. Agric. Food Chem. 2004, 52, 6646-6652. [CrossRef] [PubMed]

47. Ferreira, I.; Barros, L.; Abreu, R. Antioxidants in Wild Mushrooms. Curr. Med. Chem. 2009, 16, 1543-1560. [CrossRef] [PubMed]

48. Lim, Y.Y.; Murtijaya, J. Antioxidant properties of Phyllanthus amarus extracts as affected by different drying methods. LWT Food Sci. Technol. 2007, 40, 1664-1669. [CrossRef]

49. Toor, R.K.; Savage, G.P. Effect of semi-drying on the antioxidant components of tomatoes. Food Chem. 2006, 94, 90-97. [CrossRef]

50. Chan, E.W.C.; Lim, Y.Y.; Wong, L.F.; Lianto, F.S.; Wong, S.K.; Lim, K.K.; Lim, T.Y. Antioxidant and tyrosinase inhibition properties of leaves and rhizomes of ginger species. Food Chem. 2008, 109, 477-483. [CrossRef]

51. Dewanto, V.; Wu, X.; Adom, K.K.; Liu, R.H. Thermal Processing Enhances the Nutritional Value of Tomatoes by Increasing Total Antioxidant Activity. J. Agric. Food Chem. 2002, 50, 3010-3014. [CrossRef]

52. Kubra, I.R.; Rao, L.J.M. Microwave drying of ginger (Zingiber officinale Roscoe) and its effects on polyphenolic content and antioxidant activity. Int. J. Food Sci. Technol. 2012, 47, 2311-2317. [CrossRef]

53. Garau, M.C.; Simal, S.; Rosselló, C.; Femenia, A. Effect of air-drying temperature on physico-chemical properties of dietary fibre and antioxidant capacity of orange (Citrus Aurantium v. Canoneta) by-products. Food Chem. 2007, 104, 1014-1024. [CrossRef]

54. Lacramioara, O.; Radu, G.A.; Andreea, V.; Marius, N.G. Effect of Freeze-drying and Oven-drying Methods on Flavonoids Content in two Romanian Grape Varieties. Revista de Chimie-Bucharest-Original Edition 2019, 70, 491-494.

55. Fan, Y.; He, X.; Zhou, S.; Luo, A.; He, T.; Chun, Z. Composition analysis and antioxidant activity of polysaccharide from Dendrobium denneanum. Int. J. Biol. Macromol. 2009, 45, 169-173. [CrossRef] [PubMed] 
56. Kolupaev, Y.Y.; Yastreb, T.O.; Karpets, Y.V.; Miroshnichenko, N.N. Influence of salicylic and succinic acids on antioxidant enzymes activity, heat resistance and productivity of Panicum miliaceum L. J. Stress Physiol. Biochem. 2011, 7, 154-163.

57. Heleno, S.A.; Ferreira, R.C.; Antonio, A.L.; Queiroz, M.-J.R.P.; Barros, L.; Ferreira, I.C.F.R. Nutritional value, bioactive compounds and antioxidant properties of three edible mushrooms from Poland. Food Bioscience 2015, 11, 48-55. [CrossRef]

58. Amarowicz, R. Antioxidant activity of Maillard reaction products. Eur. J. Lipid Sci. Technol. 2009, 111, 109-111. [CrossRef]

59. Asamoa, A.A.; Essel, E.A.; Jacob, K.; Agbenorhevi, I.; Oduro, N. Effect of Processing Methods on the Proximate Composition, Total Phenols and Antioxidant Properties of Two Mushroom Varieties. Am. J. Food Nutr. 2018, 6, 55-59. [CrossRef]

60. Kang, K.S.; Yamabe, N.; Kim, H.Y.; Okamoto, T.; Sei, Y.; Yokozawa, T. Increase in the free radical scavenging activities of American ginseng by heat processing and its safety evaluation. J. Ethnopharmacol. 2007, 113, 225-232. [CrossRef]

61. Čechovská, L.; Cejpek, K.; Konečný, M.; Velíšek, J. On the role of 2,3-dihydro-3,5-dihydroxy-6-methyl-(4H)-pyran-4-one in antioxidant capacity of prunes. Eur. Food Res. Technol. 2011, 233, 367-376. [CrossRef]

62. Muszyńska, B.; Grzywacz-Kisielewska, A.; Kała, K.; Gdula-Argasińska, J. Anti-inflammatory properties of edible mushrooms: A review. Food Chem. 2018, 243, 373-381. [CrossRef]

63. Rzhepakovsky, I.V.; Timchenko, L.D.; Areshidze, D.A.; Avanesyan, S.S.; Budkevich, E.V.; Piskov, S.I.; Mannino, S.; Lodygin, A.D.; Kovalev, D.A.; Kochergin, S.G. Antioxidant activity of chicken embryo tissues powder obtained by different methods of hydrolysis. J. Hyg. Eng. Des. 2019, 27, 127-133.

64. Cheung, L.M.; Cheung, P.C.K. Mushroom extracts with antioxidant activity against lipid peroxidation. Food Chem. 2005, 89, 403-409. [CrossRef]

65. Kim, M.-J.; Chu, W.-M.; Par, E.J. Antioxidant and antigenotoxic effects of shiitake mushrooms affected by different drying method. J. Korean Soc. Food Sci. Nutr. 2012, 41, 1041-1048. [CrossRef]

66. Manimaran, M.; Kannabiran, K. Marine Streptomyces Sp. VITMK1 Derived Pyrrolo [1, 2-A] Pyrazine-1, 4-Dione, Hexahydro-3-(2-Methylpropyl) and Its Free Radical Scavenging Activity. Open Bioact. Compd. J. 2017, 5, 23-30. [CrossRef]

67. Ibadallah, B.; Abdullah, N.; Shuib, A. Identification of Angiotensin-Converting Enzyme Inhibitory Proteins from Mycelium of Pleurotus pulmonarius (Oyster Mushroom). Planta Medica. 2015, 81, 123-129. [CrossRef]

68. Manoharan, S.; Shuib, A.S.; Abdullah, N.; Mohamad, S.B.; Aminudin, N. Characterisation of novel angiotensin-I-converting enzyme inhibitory tripeptide, Gly-Val-Arg derived from mycelium of Pleurotus pulmonarius. Process Biochem. 2017, 62, 215-222. [CrossRef]

69. Lau, C.-C.; Abdullah, N.; Aminudin, N.; Shuib, A.S. Effect of Freeze-Drying Process on the Property of Angiotensin I-Converting Enzyme Inhibitory Peptides in Grey Oyster Mushrooms. Dry. Technol. 2013, 31, 1693-1700. [CrossRef]

(C) 2020 by the authors. Licensee MDPI, Basel, Switzerland. This article is an open access article distributed under the terms and conditions of the Creative Commons Attribution (CC BY) license (http://creativecommons.org/licenses/by/4.0/). 